Cornell University Law School Scholarship@Cornell Law: A Digital Repository

$11-2017$

\title{
From No Child Left Behind to Every Student Succeeds: Back to a Future for Education Federalism
}

Michael Heise

Cornell Law School, michael.heise@cornell.edu

Follow this and additional works at: https://scholarship.law.cornell.edu/facpub

Part of the Education Law Commons

\section{Recommended Citation}

Michael Heise, "From No Child Left Behind to Every Student Succeeds: Back to a Future for Education Federalism," 117 Columbia Law Review 1859 (2017)

This Article is brought to you for free and open access by the Faculty Scholarship at Scholarship@Cornell Law: A Digital Repository. It has been accepted for inclusion in Cornell Law Faculty Publications by an authorized administrator of Scholarship@Cornell Law: A Digital Repository. For more information, please contact jmp8@cornell.edu. 


\title{
FROM NO CHILD LEFT BEHIND TO EVERY STUDENT SUCGEEDS: BACK TO A FUTURE FOR EDUCATION FEDERALISM
}

\author{
Michael Heise*
}

When passed in 2001, the No Child Left Behind Act represented the federal government's most dramatic foray into the elementary and secondary public school policymaking terrain. While critics emphasized the Act's overreliance on standardized testing and its reduced schooldistrict and state autonomy, proponents lauded the Act's goal to close the achievement gap between middle- and upper-middle-class students and students historically ill served by their schools. Whatever structural changes the No Child Left Behind Act achieved, however, were largely undone in 2015 by the Every Student Succeeds Act, which repositioned significant federal education policy control in state governments. From a federalism standpoint, the Every Student Succeeds Act may have reset education federalism boundaries to favor states, far exceeding their position prior to 2001.

While federal elementary and secondary education reform efforts since 2001 may intrigue legal scholars, a focus on educational federalism risks obscuring an even more fundamental development in educational policymaking power: its migration from governments to families, from regulation to markets. Amid a multidecade squabble between federal and state lawmakers over education policy authority, efforts to harness individual autonomy and market forces in the service of increasing children's educational opportunity and equity have grown. Persistent demands for and increased availability of school voucher programs, charter schools, tax credit programs, and homeschooling demonstrate families' desire for greater agency over decisions about their children's education. Parents' calls for greater control over critical decisions concerning their children's education and schooling options may eclipse state and federal lawmakers' legislative squabbles over educational federalism.

INTRODUCTION .................................................................. 1860

I. EDUCATION FEDERALISM'S DYNAMIC FLUIDITY..............................1864

A. Vertical Separation of Powers ..............................................1865

1. Pre-No Child Left Behind Act (NCLB) . ..........................1865

2. The No Child Left Behind Act......................................1866

* Professor, Cornell Law School. Thanks to Professors Derek Black and Dawn M. Chutkow for helpful comments on an earlier version of this Essay. 
3. Pushing NCLB to (or Beyond) Federalism's Breaking Point

4. The Every Student Succeeds Act.......................................1872

B. Horizontal Separation of Powers-U.S. Department of

Education "Dear Colleague" Letters..........................................1875

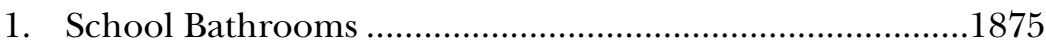

2. Student Sexual Assault ......................................................1878

3. "Dear Colleague" Letters' Implications for Horizontal Separation of Power........................................................1880

II. SCHOOL CHOICE's PERSISTENT GROWTH ............................................1881

A. Evidence of Increased School Choice .....................................1882

1. Charter and Magnet Schools ............................................1883

2. Private Schools and Voucher Programs..............................1885

3. Homeschooling and Online Education ............................1887

B. Education Spending: The 2007-2008 Financial Crisis and Its Implications for School Choice ............................................188

1. Education Spending .......................................................1888

2. Consequences for School Choice ………...........................1890

C. Demand for Public School: A Comparatively Smaller Slice of a Shrinking Pie. .1891

III. WHAT A FOCUS ON TRADITIONAL EDUCATION FEDERALISM RISKS

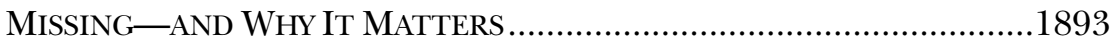

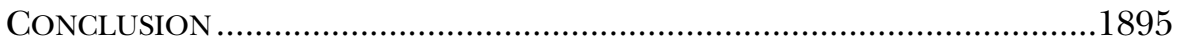

\section{INTRODUCTION}

From a formal legal perspective, the initial years of the twenty-first century unmasked the nation's growing uncertainty about K-12 education federalism. America's long and deep tradition of local control over general education policy began to erode as the federal government entered discrete K-12 regulatory spaces, largely incident to President Lyndon Johnson's War on Poverty. ${ }^{1}$ Despite discrete federal regulatory pockets targeting specific challenges to identifiable student subpools, through the end of the twentieth century, few contested the point that, in general, education policymaking fundamentally remained a state and

1. See, e.g., Every Student Succeeds Act, Pub. L. No. 114-95, 129 Stat. 1802 (2015) (reauthorizing and amending the Elementary and Secondary Education Act (ESEA) that was initially enacted in 1965). For a recent discussion of Title I of the Elementary and Secondary Education Act of 1965 and its purposes, see James S. Liebman \& Michael Mbikiwa, Every Dollar Counts: In Defense of the Obama Department of Education's "Supplement Not Supplant" Proposal, 117 Colum. L. Rev. Online 36, 38-41 (2017), http://columbialawreview.org/content/every-dollar-counts-in-defense-of-the-obama-departmentof-educations-supplement-not-supplant-proposal/ [http://perma.cc/LAG6-Q7MD]. 
local enterprise. ${ }^{2}$ This allocation of policymaking authority largely tracked the dominance of state and local financial contributions to school budgets. ${ }^{3}$

The emergence of the twenty-first century, however, coincided with Congress enacting the No Child Left Behind Act (NCLB) and singularly upending traditional education federalism boundaries. While different people may have had different perspectives on NCLB, few contested its dramatic implications for K-12 education federalism in general and its significant expansion of the federal footprint in particular. ${ }^{4}$ Simply put, NCLB profoundly reshaped education federalism boundaries when it became law in 2001. Notwithstanding its profound implications for education federalism, however, NCLB did not fundamentally dislodge the primacy of state and local funding for most school budgets.

Despite not yet having fully digested NCLB and its implications for a more robust federal influence in K-12 education, Congress, once again, dramatically readjusted education federalism lines in 2015. The enactment of the Every Student Succeeds Act (ESSA) not only unwound federal shifts achieved through NCLB but also may have shifted K-12 policymaking authority back to the states and local districts more so than before NCLB, according to some scholars. ${ }^{5}$ ESSA's relative infancy makes it difficult to assess with accuracy how it will mature and evolve over time. While ESSA's efficacy as a matter of policy remains similarly unclear at this time, what is already quite clear, however, is ESSA's effect on education federalism. To complicate education federalism matters further, at the same time that Congress toggled between NCLB and ESSA and unsettled vertical separation of power understandings, the executive branch disrupted long-standing horizontal separation of power balances with two "Dear Colleague" letters issued by the U.S. Department of Education's Office for Civil Rights. ${ }^{6}$ Quite aside from-but nonetheless related to-the dramatic shifts in education federalism boundaries themselves, a related point involves the increased velocity and rapidity of such dramatic reassignments of policymaking authority between the

2. See generally Natalie Gomez-Velez, Public School Governance and Democracy: Does Public Participation Matter?, 53 Vill. L. Rev. 297, 301-08 (2008) (summarizing increasing federal involvement in public education over the course of the twentieth century). 3. See infra Table 1.

4. See, e.g., Kimberly Jenkins Robinson, Disrupting Education Federalism, 92 Wash. U. L. Rev. 959, 966 (2015) [hereinafter Robinson, Disrupting] ("NCLB represents the most expansive education reform law in the history of the United States.").

5. See generally Derek W. Black, Abandoning the Federal Role in Education: The Every Student Succeeds Act, 105 Calif. L. Rev. (forthcoming 2017) [hereinafter Black, Abandoning] (manuscript at 131-33) (on file with the Columbia Law Review) (noting that "whatever federal leadership and leverage the NCLB provided, the ESSA largely eliminates it" and that ESSA "moves the Elementary and Secondary Education Act backward, transforming more of the existing funds into block grants," which allow states more discretion).

6. See infra section I.B. 
federal and state and local governments over education policymaking authority.

After briefly describing these important shifts in K-12 education federalism, this Essay takes a step back in an effort to gain some perspective and helpful context. Greater analytic distance from the admittedly important federalism changes achieved through relatively recent-and dramatic-congressional and executive activity ushers into sharp relief one important yet underappreciated point: While federal and state governments continue to squabble over federalism turf in the K-12 domain, a more profound shift in education authority-a shift from governments (local, state, and federal) to parents-is well underway and increasing in velocity. While many legal scholars, including constitutional and education policy scholars, understandably focus on the vertical and horizontal separation of power dimensions raised by a succession of federal legislation and administrative activities, ${ }^{7}$ such a focus risks obscuring an equally, if not more, important long-term shift in K-12 education policymaking authority.

Evidence of an even more profound transfer of control over critical education decisionmaking authority from governments to parents and families abounds. The growing demand for charter schools, school voucher programs, tax credit programs, and homeschooling-independently and collectively-suggests that families have an almost unquenchable thirst for greater agency when it comes to decisions about their children's education. ${ }^{8}$ To be sure, many scholars note the growth of school choice in the education context. ${ }^{9}$ Similarly, education federalism scholarship also continues to grow. ${ }^{10}$ What these two distinct literatures miss, however, is how the former literature implicates the latter. Specifically, while federal and state governmental officials persist with an education federalism "tug-of-war" and Congress and the Department of Education squabble over policy turf, these governmental units are

7. See, e.g., Black, Abandoning, supra note 5 (manuscript at 105-06); Kristi L. Bowman, The Failure of Education Federalism, 51 Mich. J.L. Reform (forthcoming 2017) (manuscript at 7) (on file with the Columbia Law Review); Michael Heise, The Political Economy of Education Federalism, 56 Emory L.J. 125, 130-35 (2006) [hereinafter Heise, Political Economy]; Robinson, Disrupting, supra note 4, at 963; Kimberly Jenkins Robinson, The High Cost of Education Federalism, 48 Wake Forest L. Rev. 287, 331 (2013) [hereinafter Robinson, High Cost].

8. See infra Part II.

9. See, e.g., Terry M. Moe, Schools, Vouchers, and the American Public 21 (2001); Michael Heise, Choosing Equal Educational Opportunity: School Reform, Law, and Public Policy, 68 U. Chi. L. Rev. 1113, 1126 (2001); Michael W. McConnell, Governments, Families, and Power: A Defense of Educational Choice, 31 Conn. L. Rev. 847, 847 (1999); James E. Ryan \& Michael Heise, The Political Economy of School Choice, 111 Yale L.J. 2043, 2063-64 (2002); Aaron Jay Saiger, School Choice and States' Duty to Support "Public" Schools, 48 B.C. L. Rev. 909, 922 (2007).

10. See, e.g., Heise, Political Economy, supra note 7, at 126-27; Robinson, High Cost, supra note 7 , at 287 . 
fighting over a shrinking slice of the education policy pie. That is, while intra-government federalism battles over policymaking authority persist, parents are increasingly demanding and receiving greater control over at least one critical education decision: where their kids will attend school. A reduction in real and perceived access to quality schooling partly fuels parents' increased demand for agency over where their kids will attend school. Moreover, technological advances combine with a growing supply of high quality educational and teaching materials and ready-to-use curricula to make homeschooling an increasingly plausible option for a greater number of families. ${ }^{11}$ These factors may also disrupt existing methods of the production and distribution of education services.

While the full array of policy implications of an important shift in authority over school assignments from governments to parents remains far from clear, the rough contours of a few tentative consequences have emerged. One likely consequence is that while federal and state governments may succeed in retaining decisionmaking and policy control over the operation of public and private schools, public officials can no longer simply assume the same level of control over decisions about which students will attend which schools (public, private, or homeschools). Increased parental authority over school choice decisions complicates governments' decisions relating to school finance. Increased parental control also contributes to and reflects an increased degree of consumerism in the education space, as well as an increased desire to lever market forces in the service of education, whether public or private. Finally, increased parental consumerism and a greater influence of market forces in the education space will likely continue to both inform and disrupt how education services are presently produced and distributed.

This Essay unfolds as follows. Part I describes how federalism and separation of power boundaries in the education context remain both fluid and increasingly contested, and it places recent federal forays into elementary and secondary education into their proper historical context. Part II notes the steady growth of parental choices in the school setting over time and the persistence of its growth despite the enduring jurisdictional squabbles among federal, state, and local governments over education policy. Part III develops the claim that a focus on vertical and horizontal separation of power concerns in general and education federalism in particular risks missing a more profound change in the education policy landscape. Specifically, parents' growing calls for greater agency and control over their children's education and school options will likely eclipse political fighting over education federalism in terms of importance. The Conclusion notes that the migration of control over education control from all levels of government to parents and students represents a profound structural reallocation of power between govern- 
ments and their citizens when it comes to elementary and secondary education.

\section{EDUCATION FEDERALISM’S DYNAMIC FLUIDITY}

Despite a tradition, or at least a conventional myth, of local control that dominated education federalism for decades, ${ }^{12}$ federalism boundaries are increasingly noted for their fluidity in the public education sector. Not only are federalism boundaries becoming increasingly fluid, but the pace of change to these boundaries has also quickened over time, no doubt a reflection of increasingly contested federalism claims. Since the turn of the twenty-first century, for example, two separate federal laws, the No Child Left Behind Act of $2001^{13}$ and Every Student Succeeds Act of $2015,{ }^{14}$ dramatically restructured the balance of power between the federal government and state and local governments. In addition, two separate "Dear Colleague" letters involving the U.S. Department of Education sought, at least implicitly, to redraw separation of power boundaries between the federal government's executive and legislative branches. ${ }^{15}$

While education federalism disputes raise both vertical and horizontal separation of power concerns, most scholars emphasize the former. As a consequence, the conventional understanding of the term "education federalism" has evolved quickly into code for, at bottom, a demand for an increased federal role in elementary and secondary education. ${ }^{16}$ Certainly, for those whose education federalism frame is informed by a normative preference for a greater federal role, recent scholarly accounts of education federalism remain increasingly—and largely—negative. According to Professor Kristi Bowman, for example, and with a particular eye on the school finance context, "Education federalism is failing our children." 17 Others similarly dismiss education federalism as having "hampered past efforts to ensure equal educational opportunity as the nation considers

12. For evidence of the Supreme Court's recognition of and respect for local control, see, e.g., Milliken v. Bradley, 418 U.S. 717, 721, 752 (1974) (holding a federal court may not "impose a multidistrict, areawide remedy to a single-district de jure segregation problem absent any finding that the other included school districts" also fostered such segregation within the district in question); San Antonio Indep. Sch. Dist. v. Rodriguez, 411 U.S. 1, 44 (1973) (holding Texas's public school finance system should be given deference under strict scrutiny review). But see, e.g., Denis P. Doyle \& Chester E. Finn, Jr., American Schools and the Future of Local Control, 77 Pub. Int. 77, 77 (1984) (questioning the "legend" surrounding local control over K-12 education policy).

13. Pub. L. No. 107-110, 115 Stat. 1425 (2002).

14. Pub. L. No. 114-95, 129 Stat. 1802 (2015).

15. See infra section I.B.

16. See, e.g., Black, Abandoning, supra note 5 (manuscript at 102); Bowman, supra note 7 (manuscript at 3); Robinson, High Cost, supra note 7, at 1.

17. Bowman, supra note 7 (manuscript at 3 ). 
adopting new efforts to achieve this vital national goal." ${ }^{18}$ Finally, with specific reference to the recently enacted ESSA, Professor Derek Black warns that federal disengagement with K-12 education in favor of the states poses a fundamental threat to America's goal of and promise for equal educational opportunity. ${ }^{19}$

\section{A. Vertical Separation of Powers}

Successive substantial federal legislative forays into the K-12 education sector since 2000 reveal persistent unease with-and uncertainty about - the federal government's proper policy role in the $\mathrm{K}-12$ education setting. These federal legislative forays imply dramatically different views about vertical separation of power and, as a consequence, illustrate how education federalism boundaries have changed and how the velocity of change has increased over time.

1. Pre-No Child Left Behind Act (NCLB). — Professor Kimberly Jenkins Robinson notes, "Education federalism in the United States traditionally embraces state and local authority over education and a restricted federal role." ${ }^{20}$ Moreover, judicial decisions have traditionally supported state and local primacy in the education realm. ${ }^{21}$ This deference to state and local control over schools was far from total, however, and began to erode over time. Incident to President Johnson's "War on Poverty," in 1965, Congress passed the Elementary and Secondary Education Act (ESEA). ${ }^{22}$ While ESEA reflected a bold extension of federal authority into the nation's public elementary and secondary schools, the Act and other legislation also directed new federal funding to discrete subpools of disadvantaged students. For example, ESEA's Title I focused federal resources on the educational needs of students from low-income families, ${ }^{23}$ section 504 of the Rehabilitation Act targeted federal funds for students with special needs, ${ }^{24}$ and Title IX helped ensure that students were not discriminated against by virtue of their gender. ${ }^{25}$

18. Robinson, High Cost, supra note 7, at 331.

19. See Black, Abandoning, supra note 5 (manuscript at 133) (noting the shift of power toward states is cause for concern in light of the states' track records on equal educational opportunity absent federal intervention).

20. Robinson, High Cost, supra note 7, at 287.

21. See supra note 12 and accompanying text.

22. Pub. L. No. 89-10, 79 Stat. 27 (1965).

23. See, e.g., President Lyndon B. Johnson, Johnson's Remarks on Signing the Elementary and Secondary Education Act (Apr. 11, 1965), http://www.lbjlibrary.org/ lyndon-baines-johnson/timeline/johnsons-remarks-on-signing-the-elementary-and-secondaryeducation-act [http://perma.cc/F3RX-EUDV] ("[ESEA] represents a major new commitment of the federal government to quality and equality in the schooling that we offer our young people." (emphasis added)).

24. See 29 U.S.C. $\$ 794$ (2012).

25. See 20 U.S.C. $\$ 1681$ (a) (2012). 
It is one thing for federal programs to focus on discrete student subpools, but it is quite another for federal programs to engage with broader elementary and secondary education policy. And while early federal legislation began targeting specific subpools of students, it wasn't until 1994 and the passage of the Improving America's Schools Act $(\text { IASA })^{26}$ that Congress widened its regulatory scope and posture and took aim at broader policy issues (for example, states' standards and assessments) that implicated all elementary and secondary schools and students. Despite the federal government's increasingly robust policy presence in K-12 schools, prior to 2000 and NCLB's emergence, the thrust of the federal government's involvement was generally targeted to specific policy objectives and discrete student subpools. It is worth noting, however, that a characterization of Congress's policymaking role in $\mathrm{K}-12$ education up to 2001 that emphasizes its limitations is not meant to diminish the federal government's important and growing presence in the nation's schools. For example, one critical facet of a multidecade and, to some extent, ongoing effort to desegregate and integrate public schools played out in the nation's federal courts. ${ }^{27}$

2. The No Child Left Behind Act. - Regardless of how one chooses to frame the federal government's traditional role in $\mathrm{K}-12$ education prior to NCLB, few quibble with the proposition that NCLB introduced a qualitatively new degree and breadth of federal engagement with education policy. ${ }^{28}$ Having previously required states to develop, articulate, and implement their own academic standards and assessments in 1994, fewer than ten years later, in 2001, Congress, in a bipartisan effort, set out to establish a federal statute that sought to close and, indeed, eliminate persistent academic achievement gaps among various subpools of students. The resulting legislation, NCLB, reflected perhaps the broadest, deepest, and most significant federal foray into the elementary and secondary school domain. ${ }^{29}$

NCLB's legal and policy significance flows partly from its vast scope, which implicated every public K-12 school regardless of whether the school received Title I funding. ${ }^{30}$ In exchange for the promise of

26. Pub. L. No. 103-382, 108 Stat. 3518 (1994).

27. For one recent discussion of this point, see, e.g., Chinh Q. Le, Racially Integrated Education and the Role of the Federal Government, 88 N.C. L. Rev. 725, 730 (2010) (describing the powerful Brown $v$. Board of Education mandate in a discussion of the federal government's role in school integration). See generally Richard Kluger, Simple Justice: The History of Brown v. Board Of Education and Black America's Struggle For Equality (1977) (discussing the historical and legal context of Brown v. Board of Education).

28. See, e.g., Robinson, Disrupting, supra note 4, at 966.

29. See, e.g., Robinson, High Cost, supra note 7, at 322-23.

30. NCLB involves every state because all receive some level of federal Title I funding. See Revised ESEA Title I LEA Allocations-FY 2016, U.S. Dep’t of Educ., http:// www2.ed.gov/about/overview/budget/titlei/fy16/index.html [http://perma.cc/Y63J-GMRG] (last visited Aug. 29, 2017) (presenting the Title I allocations for each state, plus the District of Columbia and Puerto Rico, in the 2016 fiscal year). For a helpful summary of 
additional federal financial support, NCLB required states to meet a series of outcome-based student-achievement benchmarks. ${ }^{31}$ The engine that drove this exchange relied on fuel supplied by state-determined standard-and-assessment regimes. ${ }^{32}$ The ignition spark involved federally enforced accountability measures that pivoted on determinations of adequate yearly progress for student academic achievement ${ }^{33}$ measured by annual student testing. ${ }^{34}$ In so doing, however, Congress "substantially expanded and restructured the federal role in elementary and secondary education and ... ultimately shaped a new educational federalism." ${ }^{35}$

In the service of the federal government's effort to help improve student achievement and close nagging achievement gaps, NCLB reset the education federalism boundary in a manner substantially more favorable to federal authority. Mindful that federalism boundaries still existed and aware of the Supreme Court's Dole test ${ }^{36}$ in particular, federal lawmakers self-consciously sought to avoid constitutional overreach in crafting NCLB. For example, rather than impose a single, uniform federal student assessment measure upon states, NCLB instead required the states themselves to develop such assessments ${ }^{37}$ and submit them for federal approval. ${ }^{38}$ One aspect that came closest to an imposition of a federal test, mandating state participation in the National Assessment of Educational Progress (NAEP) testing program, ${ }^{39}$ notably did not trigger any NCLB consequences for either states or districts. It is important to note that " $[\mathrm{r}]$ egardless of the reasons and motivations for Congress's decisions, even NCLB's harshest critics must applaud the strategic genius it embodies: an elegant use of political-economic leverage that generates policy coercion upon states that extends far beyond the reach of NCLB funds." ${ }^{40}$

NCLB's key parts, see James E. Ryan, The Perverse Incentives of the No Child Left Behind Act, 79 N.Y.U. L. Rev. 932, 939-43 (2004) [hereinafter Ryan, Perverse Incentives] (arguing NCLB pursues laudable goals but generates important, unexpected consequences).

31. 20 U.S.C. $\$ 6311$ (b) (2) (2012). For a helpful overview see generally Ryan, Perverse Incentives, supra note 30 .

32. 20 U.S.C. $\$ 6301(1)$.

33. Id. $\S 6311$ (b) (2).

34. Id. §6311(b) (2) (G).

35. Robinson, High Cost, supra note 7, at 323. However, some scholars view NCLB as merely "evolutionary" rather than "revolutionary." See, e.g., Lorraine M. McDonnell, No Child Left Behind and the Federal Role in Education: Evolution or Revolution?, 80 Peabody J. Educ. 19, 21 (2005) (suggesting NCLB did not revolutionize federal education policy, but rather was a new version of a type of policy that has historical roots).

36. See South Dakota v. Dole, 483 U.S. 203, 207-08 (1987) (outlining factors for a court to consider when determining the constitutionality of congressional action under the Spending Clause).

37. 20 U.S.C. $\$ 6311(b)(3)$.

38. Id. $\$ 6311$ (a) (1).

39. Id. $\$ 6311$ (c) (2).

40. Heise, Political Economy, supra note 7, at 141. 
NCLB deftly navigated the conditional spending authority requirements articulated by the Court's then-interpretation of South Dakota v. Dole. ${ }^{41}$ By strategically leveraging limited federal authority and applying this authority to the standards and assessments that the states themselves developed and implemented through NCLB, the U.S. Department of Education accomplished indirectly what, in all likelihood, it could not have regulated directly. ${ }^{42}$

Even a nimble (and, candidly, creative and entrepreneurial) exercise of federal authority cannot easily escape important federalism questions, however. NCLB raised-but did not squarely confront-a critical structural education federalism question: whether to decouple education policy authority and funding responsibility. More specifically, NCLB raised the question of whether, from a policy perspective, it is prudent to permit the federal government to influence elementary and secondary school policy beyond the extent of the federal government's financial contribution to state and local school district budgets.

While some understood NCLB as a creative-if unusually aggressiveuse of federal authority, other scholars were not as generous in their assessments. For example, then-Professor James Ryan (now Dean of Harvard's Graduate School of Education) zeroed in on the very factor that-while probably necessary for NCLB to claim sufficient constitutional authority and likely necessary for political passage-nonetheless generated criticism. What Ryan found particularly troublesome about NCLB was that, although it assigned the federal government authority to sanction states for failing to meet academic standards and assessments, it assigned to states the right to define student assessment thresholds. ${ }^{43}$ Ryan went on to note that resolving NCLB's internal structural problem would have required the federal government to "get off the federalism fence." ${ }^{44}$ In the end, some of NCLB's structural problems-whether necessitated by federalism concerns or not-became quickly exposed as states, confronting the perceived or real threat of federal sanctions for failing to achieve adequate yearly progress, transformed academic standards

41. See id. at 130-35 (arguing that NCLB stresses-though does not necessarily violate-the conditional spending requirements articulated in Dole).

42. In the interest of full disclosure, I was among those who argued that NCLB was not necessarily unconstitutional. My argument at that time assumed that NCLB did not impermissibly coerce state and local school districts because its conditional spending was better understood as a reimbursement rather than as a regulatory mandate. I concluded that while NCLB certainly pushed the envelope of education federalism boundaries through its strategic use of political-economic leverage, it did not constitute an unconstitutional act of statutory coercion despite evidence of the Act's "coercion" plainly visible in the education policy domain. See id. at 156.

43. See Ryan, Perverse Incentives, supra note 30, at 944; James E. Ryan, The Tenth Amendment and Other Paper Tigers: The Legal Boundaries of Education Governance, in Who's in Charge Here?: The Tangled Web of School Governance and Policy 43, 53-54 (Noel Epstein ed., 2004); see also Robinson, High Cost, supra note 7, at 325.

44. Ryan, Perverse Incentives, supra note 30, at 987. 
and assessments setting authority into a "race to the bottom." 45 This policy outcome, a net reduction in state assessment thresholds, while perhaps inevitable, defeated NCLB's broad policy objectives.

3. Pushing NCLB to (or Beyond) Federalism's Breaking Point. — Even many of NCLB's critics did not fully anticipate the federal government's next legal move. Under NCLB, states were statutorily obligated to make adequate yearly progress toward 100\% student proficiency in English and math by 2014. ${ }^{46}$ However, such a statutory mandate was, as Professor Black describes, "unrealistic under any circumstances." ${ }^{47}$ As NCLB's obligations "came due" for many states—something conceptually analogous to a "balloon mortgage" 48 preparing to explode-what became obvious to all, particularly the states, was that without statutory relief, virtually all states were in jeopardy of losing eligibility for federal funding, which constitutes roughly ten percent of an average school district's budget. ${ }^{49}$ Indeed, by 2012, eighty percent of the nation's public schools were predicted to fail to achieve adequate yearly progress under NCLB and, thus, were exposed to an array of consequences under federal law. ${ }^{50}$

Absent congressional reauthorization, NCLB was set to automatically expire in 2007.51 Many states' difficulties with meeting their own proficiency benchmarks made it abundantly clear to most observers that NCLB's reauthorization would involve more than mere tinkering and,

45. For a discussion and examples, see Heise, Political Economy, supra note 7, at 143-47; Paul T. O’Neill, High Stakes Testing Law and Litigation, 2003 BYU Educ. \& L.J. 623, 657-59 (discussing suburban backlashes against standardized testing); Paul E. Peterson \& Frederick M. Hess, Few States Set World-Class Standards, Educ. Next, Summer 2008, at 70, 73 (" $[\mathrm{A}] \mathrm{t}$ the 8th-grade level, standards are falling across the board-in both reading and math.”); see also Ryan, Perverse Incentives, supra note 30, at 948 n.77; David J. Hoff, States Revise the Meaning of 'Proficient,' Educ. Wk. (Oct. 9, 2002), http://www.edweek.org/ ew/articles/2002/10/09/06tests.h22.html (on file with the Columbia Law Review); Diana Jean Schemo, Sidestepping of New School Standards Is Seen, N.Y. Times (Oct. 15, 2002), http:/ / www.nytimes.com/2002/10/15/us/sidestepping-of-new-school-standards-is-seen.html (on file with the Columbia Law Review).

46. Pub. L. No. 107-110, § 1111(b) (2) (F), 115 Stat. 1425, 1440 (2002); see also Black, Abandoning, supra note 5 (manuscript at 115); Derek W. Black, Civil Rights, Charter Schools, and Lessons to Be Learned, 64 Fla. L. Rev. 1723, 1752-56 (2012) [hereinafter Black, Lessons].

47. Black, Abandoning, supra note 5 (manuscript at 117); see also Black, Lessons, supra note 46 , at $1752-56$.

48. Under traditional "balloon" mortgages, a large percentage of the loan's remaining principle is due at the end of the mortgage period. For a discussion of how this conceptback-ending requirements-applies in the NCLB context, see, e.g., Andrew Spitser, School Reconstitution Under No Child Left Behind: Why School Officials Should Think Twice, 54 UCLA L. Rev. 1339, 1379-83 (2007).

49. See Black, Abandoning, supra note 5 (manuscript at 118 n.113) (citing Derek W. Black, Federalizing Education by Waiver?, 68 Vand. L. Rev. 607, 611 (2015) [hereinafter Black, Federalizing]).

50. See Black, Lessons, supra note 46, at 1753-57.

51. No Child Left Behind Act $§ 1002$. 
instead, require a substantial statutory overhaul. ${ }^{52}$ The financial crisis and health care reform legislation certainly contributed to a political climate that resulted in inattention to and a delay of NCLB's necessary reauthorization. ${ }^{53}$

A political inability or unwillingness to reauthorize NCLB, combined with a growing number of states' failure to achieve adequate yearly progress, set up an inevitable political collision. ${ }^{54}$ This collision approached, accelerated by a swelling political backlash against NCLB. ${ }^{55}$ Perhaps sensing a policy opening or frustrated with Congress's neglect of NCLB's needed reauthorization, the Obama Administration began to leverage NCLB ever further. Specifically, in 2011, Education Secretary Arne Duncan implemented a policy of granting states relief from NCLB in the form of administrative waivers. ${ }^{56}$ Even more troubling, however, was that Secretary Duncan imposed conditions on those states requesting federal regulatory waivers. For states, the political "price" of a waiver included an agreement to adopt specific favored federal education policies, notably the Common Core Standards. ${ }^{57}$ As even ardent supporters of a robust federal presence in K-12 education concede, Secretary Duncan's waiver actions lacked "any specific legislative authority." 58 As a consequence of his actions, and untethered from federal law, Secretary Duncan succeeded in federalizing "core aspects of education in just a few short months." ${ }^{29}$

By using the administrative waiver process as "a substitute for the legislative process," the Obama Administration functionally worked around traditional lawmaking institutions, notably Congress, and, in so doing, redrew separation of power boundaries and encroached upon states' sovereignty. ${ }^{60}$ Anxious to avoid the stigma of having schools labeled by

52. See Black, Lessons, supra note 46, at 1756 (noting NCLB set unrealistic performance expectations that were unlikely to be met by states).

53. See Black, Abandoning, supra note 5 (manuscript at 120).

54. Id. (noting during the 2011-2012 school year approximately " 80 percent of the nation's schools would fail to meet [NCLB's] requirements").

55. See, e.g., Kamina Aliya Pinder, Federal Demand and Local Choice: Safeguarding the Notion of Federalism in Education Law and Policy, 39 J.L. \& Educ. 1, 29 (2010) (discussing reasons for backlash against NCLB, which included the lack of national curriculum and limited district control over academic objectives because of NCLB's focus on test-driven behaviors).

56. See 20 U.S.C. $\$ 7861$ (a) (2012) (waiving statutory and regulatory requirements); see also id. $\$ 6316$ (outlining the school improvement process and the onerous corrective actions imposed on schools that fail to meet achievement targets).

57. Black, Federalizing, supra note 49, at 611; see also Judson N. Kempson, Comment, Star-Crossed Lovers: The Department of Education and the Common Core, 67 Admin. L. Rev. 595, 607-18 (2015).

58. Black, Federalizing, supra note 49, at 613.

59. Id. at 611.

60. Id. at 648 . 
NCLB as "failing," states had much at stake financially and politically. ${ }^{61}$ As such, these states were unusually vulnerable to the federal government's use of political leverage. Not surprisingly, states quickly agreed to the Secretary's policy terms and conditions that attached to the regulatory waivers. By October 2013, the Department of Education had approved waiver applications for forty-three of the forty-five requesting states and the District of Columbia. ${ }^{62}$ Ironically, whatever short-term gains the states may have realized, the costs were not inconsequential. Specifically, the states' agreement to implement the federal government's preferred Common Core Standards emerged as a vibrant political issue that then-candidate Donald Trump exploited to his political benefit. ${ }^{63}$

While reasonable minds can and do differ over the efficacy of the Obama Administration's particular use of regulatory waivers in the NCLB context, the tactic clearly raises important questions about basic federalism structure, including judicially enforced lines articulated in conditional spending decisions. ${ }^{64}$ While some scholars approve of the imposition of policy conditions in exchange for federal regulatory waivers for an array of policy silos, ${ }^{65}$ such practices typically survive constitutional scrutiny only when carefully crafted supporting legislative authority exists. ${ }^{66}$ According to Professor Black, however, Secretary Duncan "lacked that authority." ${ }^{7}$ As such, the legislative workarounds pursued by Secretary Duncan in the education context fundamentally differed from analogous legislative workarounds in other policy domains. And this fundamental difference underscores the federalism concerns raised by the federal regulatory waivers from NCLB. Consequently, the federalization of education policy in the Obama Administration, however "momentous," remained "legally unfounded." 68 More specifically, in addition to separation of power and federalism concerns, Secretary Duncan's use of conditional waiver authority in this manner also may

61. See Ryan, Perverse Incentives, supra note 30, at 955-57 (noting NCLB “imposes swifter and harsher sanctions than most state systems").

62. Morgan S. Polikoff et al., Am. Enter. Inst., Grading the No Child Left Behind Waivers 4 (2014), http://www.aei.org/wp-content/uploads/2014/02/-education-outlook214_140305366436.pdf [http://perma.cc/BHE6-94EG]. See generally David J. Barron \& Todd D. Rakoff, In Defense of Big Waiver, 113 Colum. L. Rev. 265, 325-27 (2013) (discussing Congress's decision to grant the Department of Education the power to waive NCLB requirements).

63. While a candidate, President Trump repeatedly attacked Common Core and vowed to eliminate it if elected. See, e.g., Lisa Hagen, Trump Education Pick to Face Warren, Sanders, Hill (Jan. 16, 2017), http://thehill.com/homenews/administration/ 314292-trump-education-pick-to-face-warren-sanders [http://perma.cc/8DDP-XPCN].

64. Cf. Nat'l Fed'n of Indep. Bus. v. Sebelius, 132 S. Ct. 2566, 2607 (2012) ("What Congress is not free to do is to penalize States that choose not to participate in that new program by taking away their existing Medicaid funding.").

65. See, e.g., Barron \& Rakoff, supra note 62, at 334-35.

66. See id. at 312-18.

67. Black, Federalizing, supra note 49 , at 611 .

68. Id. 
have violated the Spending Clause by, in essence, "chang[ing] the rules of the game in unexpected ways." ${ }^{9}$

4. The Every Student Succeeds Act. - Once Congress refocused its attention to K-12 education legislation, it elected to replace rather than reauthorize NCLB. Years of legislative inattention, combined with an unusually aggressive use of waiver authority, fueled ESSA's enactment. ${ }^{70}$ While much about ESSA and its full effects has not yet emerged, the implications for educational federalism boundaries are already palpable. According to one of ESSA's key sponsors, Tennessee Republican Senator Lamar Alexander, ESSA represents a "significant devolution of power" over K-12 schooling from the federal government to the states. ${ }^{71}$

One critical way that ESSA departs from NCLB and enhances states' power is by permitting them to develop, test, and measure academic metrics and standards. Aside from a requirement for standards to be "challenging" (notably left undefined), ESSA now delegates to the states the task of developing academic standards. And in direct response to the Obama Administration's use of conditional waivers, ESSA expressly permits those states that previously adopted Common Core standardswhether in exchange for regulatory relief or not-to withdraw and replace those academic standards. ${ }^{72}$

More dramatic differences between NCLB and ESSA exist in the accountability domain. Actual consequences for failure to achieve adequate annual testing results typically reside at the structural core of any accountability regime. To this end, one of NCLB's pillars was that it held states and districts accountable for failures to achieve adequate yearly progress, ${ }^{73}$ and the consequences became increasingly severe for persistent failures. ${ }^{74}$ Indeed, in many ways, the political pressure from a growing number of states and districts worried about their exposure under NCLB helps explain the states' appetite for the Obama Administration's unusually aggressive use of regulatory waivers.

In comparison to NCLB, ESSA affords states far greater latitude in annual test results' deployment. Under ESSA states are now free to dilute

69. Id. at 615 .

70. See supra note 62 and accompanying text (discussing states' heavy reliance on the regulatory waivers).

71. Alyson Klein, ESSA Architect Q\&A: Sen. Lamar Alexander, R-Tenn., Educ. Wk.: Politics K-12 (June 13, 2016), http://blogs.edweek.org/edweek/campaign-k-12/2016/ 06/essa_architect_q_a_sen_lamar_a.html (on file with the Columbia Law Review).

72. Pub. L. No. 114-95, § 8544, 129 Stat. 1802, 2119 (2015); see also Jessica BulmanPozen, Executive Federalism Comes to America, 102 Va. L. Rev. 953, 989-91 (2016) (finding that " $[\mathrm{i}] \mathrm{n}$ substance, the ESSA renders 'null and void' the waivers granted in recent years by the Department of Education to states and consortia").

73. See, e.g., Spitser, supra note 48, at 1364-66 (describing the adverse consequences triggered by NCLB).

74. Pub. L. No. 107-110, § 1116(b) (5), 115 Stat. 1425, 1482-83 (2002); see also Heise, Political Economy, supra note 7, at 135. 
yearly testing results' weight when it comes to annual school, district, and teacher performance. ${ }^{75}$ That is, ESSA largely relieves states and districts from the federal consequences that flow from inadequate yearly student academic progress. In its place, ESSA imposes potential federal sanctions and requires states to intervene in only a discrete, small subset of schools: those in the bottom five percent of a state and those high schools with graduation rates below sixty-seven percent. ${ }^{76}$ Nesting standards-setting and accountability mechanisms in federal authority under NCLB was among NCLB's hallmarks. ESSA, in contrast, affords states greater autonomy, both in terms of control over substantive standards setting and the consequences for states that fail to achieve their own self-defined achievement goals.

Finally, in a largely symbolic - though nonetheless notable-gesture, ESSA expressly limits the ability of the U.S. Secretary of Education to reject or impose conditions upon state-initiated remediation plans. ${ }^{77}$ Recall that during Duncan's tenure as Education Secretary, the Department of Education engaged in what even his supporters acknowledge was an aggressive use of conditional waiver granting that, at once, relieved most states from unwelcome adverse consequences for failing to achieve adequate yearly progress under NCLB and induced states to implement a federal preference for Common Core standards. ${ }^{78}$ Rather than permit similar statutory "end-runs" by future Education Secretaries, ESSA expressly eliminated the waiver activity that took place earlier in the Obama Administration. ${ }^{79}$

Despite ample evidence illustrating how ESSA increases state authority and autonomy, it is important to note the parts of ESSA that preserve and, indeed, increase certain federal roles. For example, ESSA focuses federal attention on the bottom five percent of schools within each state as well as those high schools struggling with graduation rate problems. ${ }^{80}$ Again, from a federalism perspective the juxtaposition of NCLB and ESSA's scope could not be starker-the former functionally implicated every K-12 school while the latter restricts federal obligations to only five percent of a state's schools. ESSA's narrowed statutory focus is important for policy and political reasons. On the policy level, a focus on the lowestperforming schools may generate the necessary attention to those schools

75. Every Student Succeeds Act $§ 1005$.

76. Id.

77. Id. $\$ 8014$.

78. See supra section I.A.3.

79. Every Student Succeeds Act $\S 4(\mathrm{c})$. In limiting federal oversight, ESSA also reprimands the Department of Education (which nonetheless supported the bill) with descriptions of the many forms of authority the Department may not exercise. See, e.g., id. $\S 1005$ ("The Secretary shall not have the authority to mandate, direct, control, coerce, or exercise any direction or supervision over any of the challenging State academic standards adopted or implemented by a State.”); see also Bulman-Pozen, supra note 72, at 989-90.

80. Every Student Succeeds Act $\$ 1005$. 
most in need. On the political front, such a focus keeps the remaining ninety-five percent of schools within a state outside of the federal statute's crosshairs.

Moreover, while ESSA severely restricts the Secretary of Education's authority, some vestiges of federal oversight endure. Although states are now charged with devising their own accountability goals, states must still submit these goals to the Department of Education. ${ }^{81}$ Finally, in one discrete context-preschool education-federal policy authority increased ${ }^{82}$

On balance, however, ESSA clearly reverses the previous educational federalism boundaries established by NCLB. While NCLB may have functionally "federalized" K-12 education policy, ESSA is noted principally for redirecting education policy from the federal government back to the states. ${ }^{83}$ According to one of the leading Senate sponsors of ESSA, Senator Alexander, a resetting of education federalism boundaries in this direction was entirely consistent with the legislative intent. ${ }^{84}$

What to make of this education federalism boundary shift remains contested. Some applaud ESSA's reallocation of federal-state power in the K-12 sector on purely structural and historic grounds. ${ }^{85}$ Others, while acknowledging states' greater authority under ESSA, fear the secondary and tertiary consequences threatened by an increase in state autonomy and a corresponding decrease in federal control. ${ }^{86}$ According to its critics, who are not difficult to find, ESSA "moves education in a direction that was unthinkable just a few short years ago: no definite equity provisions, no demands for specific student achievement, and no enforcement mechanism to prompt states to consistently pursue equity or achievement." 87

Despite differing opinions on the implications of the migration from NCLB to ESSA for education federalism, many agree that the latter

81. See id.

82. See id. §921.

83. Black, Abandoning, supra note 5 (manuscript at 103); see also Betheny Gross \& Paul T. Hill, The State Role in K-12 Education: From Issuing Mandates to Experimentation, 10 Harv. L. \& Pol'y Rev. 299, 299 (2016) (noting ESSA “intended to return policy authority back to legislatures, governors, and state education agencies").

84. See supra text accompanying note 71. Notably, Senator Alexander served as Secretary of Education from 1991-1993 during the George H.W. Bush Administration. Alexander, Lamar, Biographical Directory of the U.S. Cong., http://bioguide.congress.gov/ scripts/biodisplay.pl?index=a000360 [http://perma.cc/XR22-VBLT] (last visited Aug. 28, 2017).

85. See, e.g., Gross \& Hill, supra note 83, at 322-24 (arguing that under ESSA states may accelerate progress toward more effective schools).

86. See, e.g., Black, Abandoning, supra note 5 (manuscript at 103-06) (emphasizing the negative impacts of ESSA on low-income students and equal educational opportunity); Deena Dulgerian, The Impact of the Every Student Succeeds Act on Rural Schools, 24 Geo. J. on Poverty L. \& Pol'y 111, 130-35 (2016) (describing ESSA's adverse consequences on rural schools).

87. Black, Abandoning, supra note 5 (manuscript at 103). 
reflects a more "state-centric law." 88 And if enhancing state autonomy in the K-12 policy sphere by diluting federal authority were not enough, ESSA also voids all waivers previously granted by the Department of Education. ${ }^{89}$ Indeed, some commentators note that ESSA will, eventually, "supersede the many waivers offered to some forty-two states to the NCLB requirements which the Obama administration had used to buy political time while moving education reform forward." 90

\section{B. Horizontal Separation of Powers-U.S. Department of Education "Dear Colleague" Letters}

While much of the public attention to Education Secretary Betsy DeVos's nomination dwelled on her prior public endorsements of and support for an array of school choice measures, including charter schools and vouchers, ${ }^{91}$ comparatively less appreciated is the Trump Administration's posture on horizontal separation of power issues raised by two "Dear Colleague" letters issued by the Education Department during the Obama Administration concerning Title IX.

1. School Bathrooms. - In 2016, North Carolina enacted a law, known as House Bill 2, that, among other things, defined student gender as a student's sex assigned at birth (or "biological" sex) for purposes of access to public school bathrooms. ${ }^{92}$ The Justice Department under President Obama informed the North Carolina Governor that the North Carolina law violated federal antidiscrimination laws. ${ }^{93}$ Then-Governor

88. See, e.g., Bulman-Pozen, supra note 72, at 991 (arguing that ESSA "diminishes federal involvement in education" and, as compared to NCLB, is a more "state-centric" law); see also supra note 71 and accompanying text (quoting Senator Alexander describing ESSA as a "significant devolution of power" from the federal government to the states).

89. Pub. L. No. 114-95, 129 Stat. 1802, 1806 (2015). For a discussion of the way in which ESSA addresses the Department of Education's waiver activity under the Obama Administration, see Bulman-Pozen, supra note 72, at 990 n.151.

90. Joel Rogers, Foreword: Federalism Bound, 10 Harv. L. \& Pol'y Rev. 281, 291 (2016).

91. See, e.g., Editorial, Big Worries About Betsy DeVos, N.Y. Times (Jan. 10, 2017), http://www.nytimes.com/2017/01/10/opinion/big-worries-about-betsy-devos.html (on file with the Columbia Law Review) ("She has poured money into charter schools advocacy, winning legislative changes that have reduced oversight and accountability. About 80 percent of the charter schools in Michigan are operated by for-profit companies, far higher than anywhere else."); see also Michael A. Naclerio, Note, Accountability Through Procedure? Rethinking Charter School Accountability and Special Education Rights, 117 Colum. L. Rev. 1153, 1159-61 (2017) (describing ways in which charter schools are functionally and legally distinct from traditional school districts).

92. An Act to Provide for Single-Sex Multiple Occupancy Bathroom and Changing Facilities in Schools and Public Agencies and to Create Statewide Consistency in Regulation of Employment and Public Accommodations, Sess. L. No. 2016-3, § 1.2, 2016 N.C. Sess. Laws 12, 12-13.

93. See Complaint for Declaratory Judgment at 1-2, McCrory v. United States, No. 5:16-cv-00238-BO (E.D.N.C. filed May 9, 2016) (on file with the Columbia Law Review) 
Pat McCrory quickly filed a lawsuit seeking declaratory relief vindicating his state's law. ${ }^{94}$ On that same day, the Justice Department filed its own lawsuit asking a federal court to declare that the North Carolina law violated federal law. ${ }^{95}$

While North Carolina subsequently repealed House Bill 2, the debate it ignited persists. ${ }^{96}$ On May 13, 2016, the Obama Administration's Office for Civil Rights in the Department of Education (OCR) and Civil Rights Division of the Department of Justice released a "Dear Colleague" letter to all recipient institutions bound by Title IX designed to prohibit discrimination based on a student's gender identity. ${ }^{97}$ Specifically, the letter asserts that for Title IX purposes the federal government "treat[s] a student's gender identity as the student's sex." 98

OCR's "Dear Colleague" letter expressly purported to provide "significant guidance" rather than expand Title IX's legal obligations on schools. ${ }^{99}$ While the letter implicated an array of school activities and programs, ${ }^{100}$ in the public's mind the issue became quickly joined with growing disputes over "restroom access" and the implications for transgender students. ${ }^{101}$ Despite the continued public and growing legal atten-

("The United States, through its Department of Justice ... threatened legal action against Governor McCrory, Secretary Perry, and others, because plaintiffs intend to follow North Carolina law requiring public agencies to generally limit use of multiple occupancy bathroom and changing facilities to persons of the same biological sex.").

94. Id. at 8-9. This lawsuit, filed by Governor McCrory, was subsequently voluntarily dismissed without prejudice in light of the Justice Department's own lawsuit. Plaintiff's Notice of Voluntary Dismissal Without Prejudice at 3, McCrory, No. 5:16-cv-00238-BO (E.D.N.C. filed Sept. 16, 2016) (on file with Columbia Law Review).

95. United States v. North Carolina, No. 1:16CV425, 2016 WL 4005839, at *1 (M.D.N.C. July 25, 2016).

96. See, e.g., Richard Fausset, Bathroom Law Repeal Leaves Few Pleased in North Carolina, N.Y. Times (Mar. 30, 2017), http://www.nytimes.com/2017/03/30/us/northcarolina-senate-acts-to-repeal-restrictive-bathroom-law.html?_r=0 (on file with the Columbia Law Review) (describing various interest group reactions to the repeal of House Bill 2).

97. Office for Civil Rights, U.S. Dep't of Educ., Dear Colleague Letter: Transgender Students 2 (May 13, 2016) [hereinafter Dear Colleague Letter: Transgender Students], http://www.ed.gov/ocr/letters/colleague-201605-title-ix-transgender.pdf [http://perma.cc/ U2FU-PV8Y].

98. Id. at 2.

99. Id. at 1 .

100. See 34 C.F.R. $\$ \S 106.4$, 106.31(a) (2016) (requiring that all recipients of federal funding assure, among other things, that they have not denied any student participation in any academic, extracurricular, or other educational program or activity on the basis of sex). Insofar as Title IX addresses an array of "educational programs and activities," OCR's "guidance" extended beyond school bathrooms. Dear Colleague Letter: Transgender Students, supra note 97 , at 1 .

101. See Dear Colleague Letter: Transgender Students, supra note 97, at 3 ("A school may not require transgender students to use [restrooms and locker rooms] inconsistent with their gender identity or to use individual-user [restrooms and locker rooms] when other students are not required to do so.”); Jeannie Suk Gersen, The Transgender Bathroom Debate and the Looming Title IX Crisis, New Yorker (May 24, 2016), http://www.newyorker.com/news/news-desk/public-bathroom-regulations-could-create-a- 
tion to the OCR "Dear Colleague" letter issued by the Obama Administration, the Trump Administration quickly withdrew it. ${ }^{102}$

The current Administration's withdrawal of the OCR "Dear Colleague" letter informed ongoing litigation. In G.G. ex rel. Grimm v. Gloucester County School Board, a transgender student sought access to the school bathroom that corresponded with the student's gender identity rather than the student's at-birth sex assignment. ${ }^{103}$ The Gloucester County School Board initially granted the transgender student's request, but after some community members expressed disapproval, the Board implemented a policy that limited students to school bathrooms that correspond with their at-birth sex assignment. ${ }^{104}$ After the adoption of the new restroom policy, the student turned to litigation and sought relief under Title IX. ${ }^{105}$ The student's request for a preliminary injunction was denied by a federal district court, which also concluded that the student failed to state a legal claim. ${ }^{106}$

The student's appeal to the Fourth Circuit, however, proved more successful. Reversing some evidentiary rulings by the trial court, the Fourth Circuit also concluded that the OCR's "Dear Colleague" letter was entitled to some degree of legal deference-specifically, Auer deference ${ }^{107}$-as it evidences the Department of Education's interpretation of Title IX. ${ }^{108}$ The Supreme Court initially stayed the matter. After agreeing to hear the appeal, the Supreme Court later decided to vacate and remand the Fourth Circuit's decision to the appeals court in light of the current Administration's withdrawal of the "Dear Colleague" letter, which figured so prominently in the Fourth Circuit's original decision. ${ }^{109}$

title-ix-crisis [http://perma.cc/9ASK-DC44] (describing the OCR's "Dear Colleague" letter and the "clear" threat that "schools that failed to comply could lose federal funding").

102. Office for Civil Rights, U.S. Dep't of Educ., Dear Colleague Letter: Withdrawal 1 (Feb. 22, 2017), http://assets.documentcloud.org/documents/3473560/Departments-ofEducation-and-Justice-roll-back.pdf [http://perma.cc/2LSE-ZD7B]. Note that the Trump Administration's withdrawal of the Dear Colleague letter on transgender students also included a withdrawal of a related Department of Education letter from Acting Deputy Assistant Secretary for Policy James Ferg-Cadima, to Emily Prince, dated January 7, 2015. Id.

103. 132 F. Supp. 3d 736, 739-41 (E.D. Va. 2015), rev'd in part and vacated in part, 822 F.3d 709 (4th Cir. 2016), vacated, 137 S. Ct. 1239 (2017) (mem.).

104. Id. at 740-41.

105. Id.

106. Id. at 744-53.

107. See Auer v. Robbins, 519 U.S. 452, 461 (1997) (holding that an agency's interpretation of its own regulations is due deference).

108. G.G. ex rel. Grimm, 822 F.3d at 719-24.

109. Gloucester Cty. Sch. Bd. v. G.G. ex rel. Grimm, 137 S. Ct. 1239, 1239 (2017) (mem.); see also Robert Barnes \& Moriah Balingit, Supreme Court Takes up School Bathroom Rules for Transgender Students, Wash. Post (Oct. 28, 2016), http:// www.washingtonpost.com/politics/courts_law/supreme-court-takes-up-school-bathroom-rules- 
2. Student Sexual Assault. - Earlier, in 2011, the OCR released another "Dear Colleague" letter, this one involving student sexual assault. ${ }^{110}$ Specifically, the Obama Administration's Education Department construed sexual assault as sexual "harassment" for purposes of Title IX. ${ }^{111}$ As Harvard Law Professor Jeannie Suk Gersen describes in a New Yorker essay, the OCR letter went on to detail specifically how schools, colleges, and universities needed to adapt their student disciplinary policies and procedures with respect to incidences of alleged sexual assault, with particular reference to lowering burden of proof standards. ${ }^{112}$ A recipient institution that failed to comply with Title IX risked losing federal funding. ${ }^{113}$

Unlike prior OCR policy guidance, including so-called "significant" policy guidance, ${ }^{114}$ the 2011 "Dear Colleague" letter did not benefit from formal administrative law notice-and-comment requirements. ${ }^{115}$ As it relates to OCR's particular directive to colleges and universities to reduce the applicable standard of proof burden to the civil preponderance threshold in campus sexual assault hearings, ${ }^{116}$ the OCR sought to justify its position on the grounds that this was the standard used in Title VII hearings. ${ }^{117}$ What makes OCR's position uncomfortable, however, is that OCR's "Dear Colleague" letter did not also adopt Title VII's protections for the accused. ${ }^{118}$ If that omission were not enough, in an ironic twist the OCR "Dear Colleague" letter also expressly recommended against some of the procedural safeguards included in Title VII. ${ }^{119}$

for-transgender-students/2016/10/28/0eece4ea-917f-11e6-a6a3-d50061aa9fae_story.html?utm_ term=.f1 e742c46d6c [http://perma.cc/J865-WT63].

110. Office for Civil Rights, U.S. Dep't of Educ., Dear Colleague Letter: Sexual Violence (Apr. 4, 2011) [hereinafter Dear Colleague Letter: Sexual Violence], http:// www2.ed.gov/about/offices/list/ocr/letters/colleague-201104.pdf [http://perma.cc/GA6V-KR8P].

111. Id. at $1-2$.

112. Id. at 11 ("Thus, in order for a school's grievance procedures to be consistent with Title IX standards, the school must use a preponderance of the evidence standard (i.e., it is more likely than not that sexual harassment or violence occurred)."); see also Gersen, supra note 101 (describing the April 2011 "Dear Colleague" letter and its ramifications).

113. 20 U.S.C. $§ 1681$ (a), (c) (2012). "Recipient institutions" bound by Title IX and exposed to its sanctions include virtually every accredited college and university in the United States as well as, by definition, all public elementary and secondary schools. Id. $\S 1681(\mathrm{c})$.

114. See Dear Colleague Letter: Sexual Violence, supra note 110, at 1 n.1.

115. See Tamara Rice Lave, A Critical Look at How Top College and Universities Are Adjudicating Sexual Assault, 71 U. Miami L. Rev. 377, 389 (2017) (describing how the 2011 letter did not "post a formal notice requesting feedback" on proposed changes).

116. See Dear Colleague Letter: Sexual Violence, supra note 110, at 11.

117. Id. at 10-11.

118. These protections include, but are not limited to, a right to demand a jury trial, cross-examine witnesses, and confront the complainant. For a discussion see Lave, supra note 115 , at 390 .

119. See id. 
Notwithstanding the procedural and substantive concerns with OCR's legal interpretation of Title IX, many schools, colleges, and universities quickly adopted campus-level policies and practices consistent with those articulated in the "Dear Colleague" letter. ${ }^{120}$ What has ensued, however, includes a string of notable and notably successful lawsuits against these very schools, colleges, and universities brought by students accused under the new OCR guidelines complaining of an array of due process violations. ${ }^{121}$ As legal and related financial exposure continues to mount for many colleges and universities on this front, ${ }^{122} \mathrm{a}$ number of higher education administrators, many of whom previously may have welcomed-indeed, encouraged-OCR's "guidance," are now quickly rethinking their position and beginning to push back against OCR's "guidance." For example, one harbinger is that while Harvard University adapted its university-wide student sexual assault code to conform with OCR "guidance," 123 Harvard Law School, alarmed by the dire due process implications for those accused and subjected to policies and procedures promoted by the OCR "Dear Colleague" letter, declined to follow the university's lead and instead developed and now employs its own set of policies and procedures that differ in critical ways from the university-wide approach. ${ }^{124}$

Indeed, similar to its earlier withdrawal of the "Dear Colleague" letter implicating school bathrooms, on September 7, 2017, in a widely anticipated speech, U.S. Education Secretary DeVos announced the Administration's decision to "revisit" the legal rules governing what Title

120. See id. at 391-98 (describing findings from a survey of top colleges and universities about the procedural protections given to students accused of sexual assault).

121. For a recent comprehensive treatment of this issue and the related litigation see generally KC Johnson \& Stuart Taylor, Jr., The Campus Rape Frenzy: The Attack on Due Process at America's Universities (2017).

122. For a brief summary of the growing —and successful-litigation against colleges and universities, see generally id. at 87-96.

123. See Harvard Univ., Sexual and Gender-Based Harassment Policy (2017), http:// titleix.harvard.edu/files/title-ix/files/harvard_sexual_harassment_policy.pdf?m=1461104544 [http://perma.cc/HZ4S-XHFD] (updating the university's policies and procedures, including its definition of sexual assault, to comply with OCR guidance). For a general summary, see, e.g., Janet Halley, Trading the Megaphone for the Gavel in Title IX Enforcement, 128 Harv. L. Rev. Forum 103, 107 \& n.9, 109 (2015), http://harvardlawreview.org/ wp-content/uploads/2015/02/vol128_Halley_REVISED_2.17.pdf [http://perma.cc/9N3C-2557].

124. See Harvard Law Sch., Interim Sexual Harassment Policy and Procedures, http://hls.harvard.edu/content/uploads/2014/09/hls-titleix-interimpolicyl.pdf [http:// perma.cc/7352-CMRU] (last visited Aug. 7, 2017) (adopting, for the 2014-2015 academic year, certain aspects of the university policies while changing other features). For emerging evidence that the Trump Administration is also now rethinking its position on the Student Sexual Assault "Dear Colleague" letter, see Erica L. Green \& Sheryl Gay Stolberg, Campus Rape Policies Get a New Look as the Accused Get DeVos's Ear, N.Y. Times (July 12, 2017), http://www.nytimes.com/2017/07/12/us/politics/campus-rapebetsy-devos-title-iv-education-trump-candice-jackson.html (on file with the Columbia Law Review) (discussing the Department of Education's readiness to reexamine Obama-era policies pertaining to students accused of sexual assault). 
IX requires of schools, colleges, and universities when policing campus sexual assault. ${ }^{125}$ Secretary DeVos expressed alarm at too many instances of "kangaroo courts" on campuses that ill-served accusers and the accused. ${ }^{126}$ Notably, she committed to a review process that, consistent with Administrative Procedure Act requirements, will involve traditional notice-and-comment of proposed rules. Despite unsurprising criticism from many interest groups, ${ }^{127}$ opinion pieces appearing in the New York Times voiced clear support for Secretary DeVos' announcement. ${ }^{128}$ While it is all but certain that the Obama Administration's 2011 "Dear Colleague" letter will be rendered moot by forthcoming actions by the current Administration, it remains thus far unclear whether Secretary DeVos will seek to formally withdraw the 2011 "Dear Colleague" letter during the pendency of the Department's review of Title IX.

3. "Dear Colleague" Letters' Implications for Horizontal Separation of Power. - Setting aside the merits of and controversies surrounding gender-identity and campus sexual-assault policies and procedures, admittedly important topics, a comparatively underappreciated issue raised by the OCR "Dear Colleague" letters involves horizontal separation of powers, particularly as related to education federalism. Specifically, the issue revealed an important conflict between Congress and the executive branch over education federalism.

A Senate Committee on Health, Education, Labor, and Pensions (HELP) hearing on June 26, 2014, illustrated this conflict and featured a particularly pointed and heated exchange between the Committee Chair, Senator Alexander, and Catherine Lhamon, an Assistant Secretary for Civil Rights at the Department of Education. ${ }^{129}$ The protracted interaction focused on technical questions involving OCR's specific legal authority to enact its desired policy changes to Title IX through its 2011 "Dear Colleague" letter. Senator Alexander worried aloud that by dressing the Department of Education's demands as "significant guidance," the Department was essentially trying to enact new "law" without adhering to the requirements imposed by the Administrative Procedure Act, notably the requirements for notice and public comment. ${ }^{130}$ According to Senator Alexander,

What you're doing [in the OCR] is writing out detailed guidance for 22 million students on 7,200 campuses, and it's

125. See Stephanie Saul \& Dana Goldstein, Betsy DeVos Says She Will Rewrite Rules on Campus Sex Assault, N.Y. Times (Sept. 7, 2017), http://www.nytimes.com/2017/ 09/07/us/devos-campus-rape.html?_r=0 (on file with the Columbia Law Review).

126. Id.

127. Id. (noting criticism from such groups as the National Women's Law Center).

128. See Bret Stephens, Opinion, Betsy DeVos Ends a Campus Witch Hunt, N.Y. Times (Sept. 8, 2017), http://www.nytimes.com/2017/09/08/opinion/betsy-devos-title-iv.html?rref= collection\%2Fcolumn\%2Fbret-stephens (on file with the Columbia Law Review).

129. Johnson \& Taylor, supra note 121, at 191-94.

130. Id. 
just-it could be your whim, your idea.... We [the U.S. Congress] make the law. You don't make the law. Where does such a guidance authority come from? ${ }^{131}$

Certainly contributing to Lhamon's misfortune and discomfort was that Senator Alexander had previously served as the Secretary of Education from 1991 to 1993 under President George H.W. Bush ${ }^{132}$ and as university president from 1988 to 1991 at the University of Tennessee ${ }^{133}$ and benefits from formal legal training. ${ }^{134}$ Within a year of Assistant Secretary Lhamon's clash with Senator Alexander, OCR officials began to publicly retreat from their original assertions, as well as from the explicit text of the "Dear Colleague" letter itself, and ultimately conceded that OCR's "Dear Colleague" letters are not, in fact, legally binding upon the recipient educational institutions despite previous public assertions to the contrary. ${ }^{135}$ Substance aside, the series of exchanges involving Senator Alexander and various OCR officials helpfully distills, isolates, and identifies conflicts that can arise between the legislative and executive federal branches when it comes to control over federal law. Increasingly, these conflicts involve education federalism.

\section{SCHOOL CHOICE’S PERSISTENT GROWTH}

In early September 2016, then-candidate Trump announced that, if elected President, he would transform $\$ 20$ billion of existing federal education funds into a block grant to states that could be deployed for the benefit of private, charter, or public schools. ${ }^{136}$ President Trump's political impulse is one of the more recent-and prominent-political reflections of a persistently growing parental demand for greater choice when it comes to K-12 education. Evidence of ever-increasing parental appetite for greater school choice is not hard to find.

131. Id.

132. In the interest of full disclosure, I served as then-U.S. Education Secretary Lamar Alexander's Deputy Chief of Staff from 1991-1992.

133. About the Office of the President, U. Tenn., http://president.tennessee.edu/ about/ [http://perma.cc/ND3L-BVHW] (last visited Aug. 29, 2017); Alexander, Lamar, supra note 84. Senator Alexander is a graduate of Vanderbilt University (B.A., 1962) and NYU Law School (J.D., 1965). Id.

134. See generally Lamar Alexander, Lamar Alexander: U.S. Senator for Tenn., http://www.alexander.senate.gov/public/index.cfm/lamaralexander [http://perma.cc/ 3X48-A24X] (last visited Aug. 7, 2017).

135. See Examining the Use of Agency Regulatory Guidance: Hearing Before the Subcomm. on Regulatory Affairs \& Fed. Mgmt. of the S. Comm. on Homeland Sec. \& Governmental Affairs, 114th Cong. 18-20 (2015) (statement of Sen. Alexander).

136. Diane Ravitch, When Public Goes Private, as Trump Wants: What Happens?, N.Y. Rev. Books (Dec. 8, 2016), http://www.nybooks.com/articles/2016/12/08/when-publicgoes-private-as-trump-wants-what-happens/ [http://perma.cc/D48Z-J7BU] [hereinafter Ravitch, Private] (reviewing Samuel E. Abrams, Education and the Commercial Mindset (2016) and Mercedes K. Schneider, School Choice: The End of Public Education? (2016)). 
Indeed, President Trump's support for increased school choice reflects a continuation of a political trend that began in earnest long before President Trump took the oath of office. A gradual shift in the production and delivery of K-12 education services from a "sectorcentered" perspective to what Professor Nicole Garnett refers to as a "child-centered" perspective has accelerated over time. ${ }^{137}$ The array of factors propelling a net growth in school choice demands includes the "exponential growth" of charter schools, complemented by a more recent increase in the availability of publicly funded school voucher programs. ${ }^{138}$ Similarly, concurrent increases in homeschool participation as well as more traditional public schools of choice (for example, magnet schools) also contribute to net increases in parental demands for greater autonomy when it comes to school decisions concerning their children. ${ }^{139}$

At the same time the supply of school options available to parents increased, one paradoxical consequence of the recently discarded NCLB also helped fuel parents' growing appetite for greater school choice. Specifically, one consequence of NCLB's testing and reporting requirements was that they laid bare persistent academic struggles in numerous public schools and districts, including some comparatively affluent suburban districts that, until NCLB, were presumed to be performing at a higher level. ${ }^{140}$ The increased availability of systematic information, however modest, about schools' academic performance propelled more parents to increase their demands for greater school choices for their children.

\section{A. Evidence of Increased School Choice}

Given the plethora of school choice options-options that exist within the public school sphere as well as options between the public and non-public school markets ${ }^{141}$-one important, though broad, barometer

137. Nicole Stelle Garnett, Sector Agnosticism and the Coming Transformation of Education Law, 70 Vand. L. Rev. 1, 6 (2017).

138. Id.; see also Michael J. Petrilli, School Reform Moves to the Suburbs, N.Y. Times (July 11, 2005), http://www.nytimes.com/2005/07/11/opinion/school-reform-moves-tothe-suburbs.html (on file with the Columbia Law Review) (explaining the negative impact that certain exceptions and flexible arrangements offered to states will have on suburban educational achievements).

139. See infra section II.A.1.

140. See Petrilli, supra note 138 ("[S] uburban schools are the most likely to post high average test scores that mask large gulfs between students of different races or classes .... The law made those achievement gaps transparent ....").

141. To be sure, how to accurately define school "choice" remains under some contest. See, e.g., Jonathan B. Cleveland, School Choice: American Elementary and Secondary Education Enter the "Adapt or Die" Environment of a Competitive Marketplace, 29 J. Marshall L. Rev. 75, 96-99 (1995); Michael Heise, Equal Educational Opportunity and Constitutional Theory: Preliminary Thoughts on the Role of School Choice and the Autonomy Principle, 14 J.L. \& Pol. 411, 413-14 (1998); Jason C. Seewer, 
of interest in school choice involves changes over time in the percentage of students attending their government "assigned" public schools. Data from the U.S. Department of Education make clear that this percentage has declined from $80 \%$ in 1993 to $73 \%$ in $2007 .{ }^{142}$ To put this $7 \%$ decline into some context, the Department of Education reports that in 2013 just over fifty million students attended public K-12 schools. ${ }^{143}$ A $7 \%$ decline in students attending their traditional government "assigned" public schools implies an approximate drop of 3.5 million students over a fifteen-year period.

Interestingly, the increased availability and flexibility of public funding helps fuel some of the attendance decline in students' assigned public schools. To be sure, flexible public funding enables some families to attend alternative public school options, such as charter and magnet schools, which are inter- and intra-district school choices. Other families, by contrast, use public funds to exercise their Pierce rights and seek out various non-public school options, including private and private religious schools, homeschooling, and virtual schools. ${ }^{144}$ Also notable is the variation of school choice options across the states. A 2013 report from the Council of Chief State School Officers notes that while all states provide at least some form of alternative to assigned public schools for some portion of students, none of the states provide all forms of school choice options to all students. ${ }^{145}$ While growth-trend curves differ across various school choice options, the cumulative effect of these options is evidence of slow and steady, if uneven, growth over time. ${ }^{146}$

1. Charter and Magnet Schools. - Public charter schools' importance in the school choice movement continues to increase over time. Between 2000 and 2014, the raw number of charter schools more than quadrupled, from 1,525 to $6,465 .{ }^{147}$ Not surprisingly, an increase in the number of

Opening the Door: A Proposal for Increased Educational Choice in Detroit, 83 U. Detroit Mercy L. Rev. 411, 415-16 (2006).

142. Sarah Grady et al., Nat'l Ctr. for Educ. Statistics, Trends in the Use of School Choice: 1993 to 2007, at 7 fig.1 (2010), http://nces.ed.gov/pubs2010/2010004.pdf [http:// perma.cc/2PYS-HEPC].

143. Nat'l Ctr. for Educ. Statistics, Digest of Education Statistics: Table 203.10. Enrollment in Public Elementary and Secondary Schools, by Level and Grade: Selected Years, Fall 1980 Through Fall 2026 (2016), http://nces.ed.gov/programs/digest/d15/ tables/dt15_203.10.asp [http://perma.cc/74WC-N8PQ].

144. See Pierce v. Soc'y of Sisters, 268 U.S. 510, 534-35 (1925) (stating the Fourteenth Amendment protects "the liberty of parents and guardians to direct the upbringing and education of children under their control").

145. Council of Chief State Sch. Officers, School Choice in the States: A Policy Landscape (2013), http://www.ccsso.org/Documents/2013/Choice_by_State_2013.pdf [http://perma.cc/HP2M-5PB2].

146. Julie F. Mead, How Legislation and Litigation Shape School Choice, in Exploring the School Choice Universe: Evidence and Recommendations 39, 41-44 (Gary Miron et al. eds., 2012) (summarizing the development of school choice initiatives since the 1950s).

147. Nat'l Ctr. for Educ. Statistics, Digest of Education Statistics: Table 216.90. Public Elementary and Secondary Charter Schools and Enrollment, By State: Selected Years, 
charter schools helped fuel a similar increase in the number of students attending charter schools. Indeed, during these same years, 2000 to 2014, charter school enrollment increased by more than $740 \% .{ }^{148}$ Finally, and perhaps most saliently, charter school enrollments grew as a percentage of total public school enrollment. In 2000, charter school enrollment accounted for less than $1 \%$ of total public school enrollment. ${ }^{149}$ By 2014, that percentage grew to $5.1 \% .{ }^{150}$ When one adds public magnet schools into this mix, the drain on traditional "assigned" public school enrollment doubles. In 2014, of the 49.7 million students attending public schools, more than 5 million, or 10 percent of, students chose to attend charter or magnet public schools-that is, to attend a public school other than a student's "assigned" public school. ${ }^{151}$

Not surprisingly, charter schools vary-sometimes tremendouslyboth within and across states. ${ }^{152}$ Although charter schools are, in a formal legal sense, public institutions, one trend within the public-charterschool market includes the growing use of private management companies to operate public charter schools. ${ }^{153}$ Interestingly, the lurch toward privatization straddles traditional political labels. ${ }^{154}$ The cumulative effect of multiple administrations over time, both Republican and Democratic, is that "there are about seven thousand publicly-funded, privatelymanaged charter schools, enrolling nearly three million students." 155

Charter schools' significant growth should not deflect attention from another genre of intra-district school choice: magnet schools. Historically, magnet schools' origins partly reflect public school districts' (typically larger urban public districts) desire to increase desegregation and student achievement through schools that usually feature particular

1999-2000 Through 2013-2014 (2015), http://nces.ed.gov/programs/digest/d15/ tables/dt15_216.90.asp [http://perma.cc/7SZN-5E3S].

148. Id. (indicating charter school enrollment increased from 339,678 to $2,519,065$ between 2000 and 2014).

149. Id.

150. Id.

151. Nat'l Ctr. for Educ. Statistics, Digest of Education Statistics: Table 216.20. Number and Enrollment of Public Elementary and Secondary Schools, by School Level, Type, and Charter and Magnet Status: Selected Years, 1990-91 Through 2013-14 (2015), http://nces.ed.gov/programs/digest/d15/tables/dt15_216.20.asp [http://perma.cc/343M-B39S].

152. See, e.g., James E. Ryan, Charter Schools and Public Education, 4 Stan. J. C.R. \& C.L. 393, 394-95 (2008).

153. See generally Preston C. Green III et al., Having It Both Ways: How Charter Schools Try to Obtain Funding of Public Schools and the Autonomy of Private Schools, 63 Emory L.J. 303 (2013) (highlighting the ways in which charter schools have used educational-management organizations and other private entities to obtain more funding from the public sector).

154. For one illustration, see, e.g., Clint Bolick, Voucher Wars: Waging the Legal Battle Over School Choice 15-43 (2003).

155. Ravitch, Private, supra note 136, at 58. 
academic focus or curricular orientation. ${ }^{156}$ While magnet schools vary in terms of their focus and efficacy, they remain an attractive option for many families. ${ }^{157}$ Indeed, both the raw number of magnet schools as well as the number of students attending them more than doubled between 2001 and 2014. ${ }^{158}$ Despite magnet schools' variety, for purposes of this Essay, the two key characteristics that bind them are that they dislodge students away from geographically assigned public schools and provide parents and students with additional education options. ${ }^{159}$

2. Private Schools and Voucher Programs. - Once-stable private religious and secular school enrollment (as measured by private school enrollment as a percentage of total school enrollment) has, since the 2008 financial crisis, displayed evidence of a slight decline. Between 1995 and 2007, the private school enrollment percentage decreased from $11.7 \%$ to $10.7 \% .{ }^{160}$ Beginning in 2009, and through 2013, the percentage dipped to $9.8 \%{ }^{161}$ The percentage decline, however, should not obscure private school's important market share of America's school children. Despite any recent minor comparative market-share decline, the total number of students participating in private school choice programs "has more than tripled in the last decade to 350,000 students in 20142015." 162 Among private school selections in 2013, families overwhelm-

156. See, e.g., Ellen Goldring \& Claire Smrekar, Magnet Schools and the Pursuit of Racial Balance, 33 Educ. \& Urb. Soc'y 17, 21 (2000) (discussing a study that found "wholeschool magnet programs (in which all students must choose the school) were the most successful in meeting desegregation goals when compared with programs in schools or mixed models of magnets and attendance zone magnets"); Kimberly C. West, A Desegregation Tool That Backfired: Magnet Schools and Classroom Segregation, 103 Yale L.J. 2567, 2568 (1994) (arguing the failure to consider classroom racial composition, and instead the reliance on school-wide racial composition, is a cause of the inefficacy of desegregation efforts in magnet schools); see also Janet R. Price \& Jane R. Stern, Magnet Schools as a Strategy for Integration and School Reform, 5 Yale L. \& Pol'y Rev. 291, 292 (1987) ("The key characteristics of a magnet school are: (1) a distinctive school curriculum organized around a special theme or method of instruction; (2) voluntary enrollment elected by students and their parents; and (3) students drawn from many attendance zones.").

157. Nat'l Ctr. for Educ. Statistics, Digest of Education Statistics: Table 216.20. Number and Enrollment of Public Elementary and Secondary Schools, by School Level, Type, and Charter and Magnet Status: Selected Years, 1990-91 Through 2013-14 (2015), http://nces.ed.gov/programs/digest/d15/tables/dt15_216.20.asp [http://perma.cc/343M-B39S].

158. Id.

159. For a brief overview see, e.g., Ryan \& Heise, supra note 9, at 2064-65.

160. Nat'l Ctr. for Educ. Statistics, Digest of Education Statistics: Table 205.10. Private Elementary and Secondary School Enrollment and Private Enrollment as a Percentage of Total Enrollment in Public and Private Schools, by Region and Grade Level: Selected Years, Fall 1995 Through Fall 2013 (2016), http://nces.ed.gov/programs/digest/ d15/tables/dt15_205.10.asp [http://perma.cc/A2FS-MQWT].

161. Id.

162. Garnett, supra note 137 , at 27. 
ingly chose religious-affiliated schools over sectarian schools $(68.1 \%$ versus $31.9 \%$, respectively). ${ }^{163}$

Voucher programs, both publicly and privately funded, seek, in part, to reduce barriers to the private school market for families. ${ }^{164}$ Early voucher programs tended to focus on either students from low-income households or students assigned to struggling public schools or both. By navigating critical open constitutional questions at that time, ${ }^{165}$ some early privately funded voucher programs operated as de facto pilot programs and, in addition to serving students and their families, set out to generate data and political support and increase the constituency for broader, more comprehensive publicly funded voucher programs. ${ }^{166}$

Contributing much to the recent growth in publicly funded voucher programs is a shift in voucher programs' initial focus on students from low-income households and those assigned to struggling public schools to a broader slice of middle-class students. While political realities typically prompted publicly and privately funded voucher programs to focus on those students most in need of additional school choices, as the politics surrounding school choice has evolved so too has voucher programs' focus. Now, ironically, successful political support for voucher programs typically requires that the programs include middle-class families as well. ${ }^{167}$

The often-uneasy relations between the private-school-voucher and charter-school movements also continue to inject political complexities into the school choice debate. While early privately funded voucher programs sought to stimulate the development of publicly funded

163. Nat'l Ctr. for Educ. Statistics, Digest of Education Statistics: Table 205.30. Percentage Distribution of Students Enrolled in Private Elementary and Secondary Schools, by School Orientation and Selected Characteristics: Fall 2011 and Fall 2013 (2015), http://nces.ed.gov/programs/digest/d15/tables/dt15_205.30.asp [http://perma.cc/ 7THV-Y69S].

164. For a discussion of some of the early major privately funded voucher programs, see generally Private Vouchers (Terry M. Moe ed., 1995). While various states and locales experimented with publicly funded voucher programs, leading up to the Supreme Court's decision in Zellman v. Simmons-Harris, 536 U.S. 639 (2002), one expression of federal support for publicly funded vouchers included the District of Columbia's Opportunity Scholarship Program, incident to the D.C. School Choice Incentive Act of 2003, Pub. L. No. 108-199, 118 Stat. 126 (2004). The Opportunity Scholarship Program was reauthorized in 2011 as the Scholarships for Opportunity and Results Act, Pub. L. No. 11210, 125 Stat. 199 (2011). For purposes of this discussion, I construe "private school voucher programs" quite broadly to include an array of technically distinct though analytically similar programs (for example, vouchers, tuition tax credits, and educationsavings accounts).

165. Specifically, prior to the Supreme Court's decision in Zellman.

166. See generally Terry M. Moe, Private Vouchers, in Private Vouchers supra note 164 , at 1, 7-9 (stating the "resort to privately funded vouchers is essentially an adaptation to political reality").

167. See Garnett, supra note 137, at 26-27 (noting a recent surge in voucher or choice programs that have far broader scope than earlier programs). 
voucher programs, one consequence was an acceleration of public charter schools' popularity. ${ }^{168}$ As the specter of increased school choice grew, so too did political resistance to it. ${ }^{169}$ And this political resistance uncovered unexpected alliances between, for example, teacher unions, reacting to the threat posed by increased private school enrollments, and traditionally "suburban Republicans," who are, in general, content with their public schools and threatened by the prospect of increasing access to them for lower-income urban students. ${ }^{170}$ As Professor Garnett notes, however, it remains possible that, in the end, the surge in charter schools and their popularity will bleed over into increased political support for school-voucher programs. ${ }^{171}$

3. Homeschooling and Online Education. - While presently the least significant in terms of the raw number of students served, homeschooling represents another and increasingly important threat to publicschool market share. In the homeschool sector, it is difficult to overestimate the influence of technological advances and the growing supply of and access to high quality education content, particularly the development of "turn-key" online education content. ${ }^{172}$ The interaction of these two factors has made homeschooling an increasingly plausible option for a far greater percentage of American families, both in terms of cost and execution. Given technological advances as well as dramatic increases in online content availability, it is not surprising that the Department of Education reports that from 2003 to 2012 the percentage of homeschooled K-12 students in the United States increased from $2.2 \%$ to $3.4 \%$, and the raw number of homeschooled children increased by almost $62 \% .{ }^{173}$

168. See Michael Heise, Law and Policy Entrepreneurs: Empirical Evidence on the Expansion of School Choice Policy, 87 Notre Dame L. Rev. 1917, 1931 (2012) (noting it "is ironic from a policy perspective ... that many school voucher supporters ... made clear their desire for such programs to stimulate broader, comprehensive publicly-funded voucher programs").

169. See generally Ryan \& Heise, supra note 9 (noting the significance of historical suburban resistance to school desegregation and school-finance reform).

170. See Garnett, supra note 137, at 25 (noting suburban Republicans are generally "happy with their public schools and unhappy about the prospect of poor urban students enrolling in them"); Ryan \& Heise, supra note 9, at 2045, 2080 ("Suburban parents are generally satisfied with the public schools their children attend, and they want to protect both the physical and the financial sanctity of these schools.").

171. Garnett, supra note 137, at 26-27.

172. Indeed, even the U.S. Department of State helps facilitate homeschooling and seeks to exploit the growing array and the use of online content resources for the benefit of Foreign Service families stationed outside of the United States. Cf. Homeschooling and Online Education, U.S. Dep't of State, http://www.state.gov/m/dghr/flo/c21941.htm [http://perma.cc/7CVF-CEDQ] (last visited Aug. 7, 2017) (outlining the Department of State's homeschooling programs for Foreign Service families).

173. Nat'l Ctr. for Educ. Statistics, Digest of Education Statistics: Table 206.10. Number and Percentage of Homeschooled Students Ages 5 Through 17 with a Grade Equivalent of Kindergarten Through 12th Grade, by Selected Child, Parent, and Household 
In addition to homeschooling growth trends, another notable wrinkle in the homeschool context is the evolving composition of households engaged in homeschooling and its deeper penetration into American society. Between 2003 and 2012, the percentage of homeschooling parents possessing a graduate or professional degree increased and the percentage of parents with no more than a high school diploma decreased. ${ }^{174}$ Similarly, the median household income of homeschooled children has increased. ${ }^{175}$ The broadening of the pool of families engaged in homeschooling has led some to characterize homeschools as "mainstream."

\section{B. Education Spending: The 2007-2008 Financial Crisis and Its Implications for School Choice}

As overall federal education spending includes far more support for an array of school choice options, trends in federal financial support for K-12 schools warrant careful attention for at least two reasons. First, while the school-finance context is one noted for sustained and protracted litigation, principally in state courts, ${ }^{177}$ the dynamic blend of education-funding sources is important for its potential federalism implications. To the extent that the federal government contributes a greater relative and absolute amount of education funding, a correlative increase in federal policy preferences would plausibly—and logically-follow. A second, and more subtle, reason involves the interaction among the various sources of public financial support for education and the 20072008 financial crisis. This interaction may have contributed to increased parental demands for school choice, which, as previously discussed, plausibly reflects and implicates a shift in education decisionmaking authority from governments to families and students.

1. Education Spending. - As Table 1 illustrates, after approximately 1980, the distribution of federal, state, and local revenue sources for public elementary and secondary schools largely stabilized. A slight disruption, primarily owing to the financial crisis of 2007-2008, emerged in the 2009-2010 school year.

Characteristics: 2003, 2007, and 2012 (2014), http://nces.ed.gov/programs/digest/d15/ tables/dt15_206.10.asp [http://perma.cc/37XE-LWSQ]. To be sure, however, the changes in these two trends over time are small and fall within the reported standard errors.

174. Id.

175. Id.

176. See Jennifer Karinen, Note, Finding a Free Speech Right to Homeschool: An Emersonian Approach, 105 Geo. L.J. 191, 194-95 (2016) (noting that homeschooling has become "much more visible and accepted").

177. See, e.g., John Dinan, School Finance Litigation: The Third Wave Recedes, in From Schoolhouse to Courthouse: The Judiciary's Role in American Education 96, 96 (Joshua M. Dunn \& Martin R. West eds., 2010) (discussing state court litigation over school finance). 
TABle 1: Source Of Revenue (PerCentage), 1920-2013178

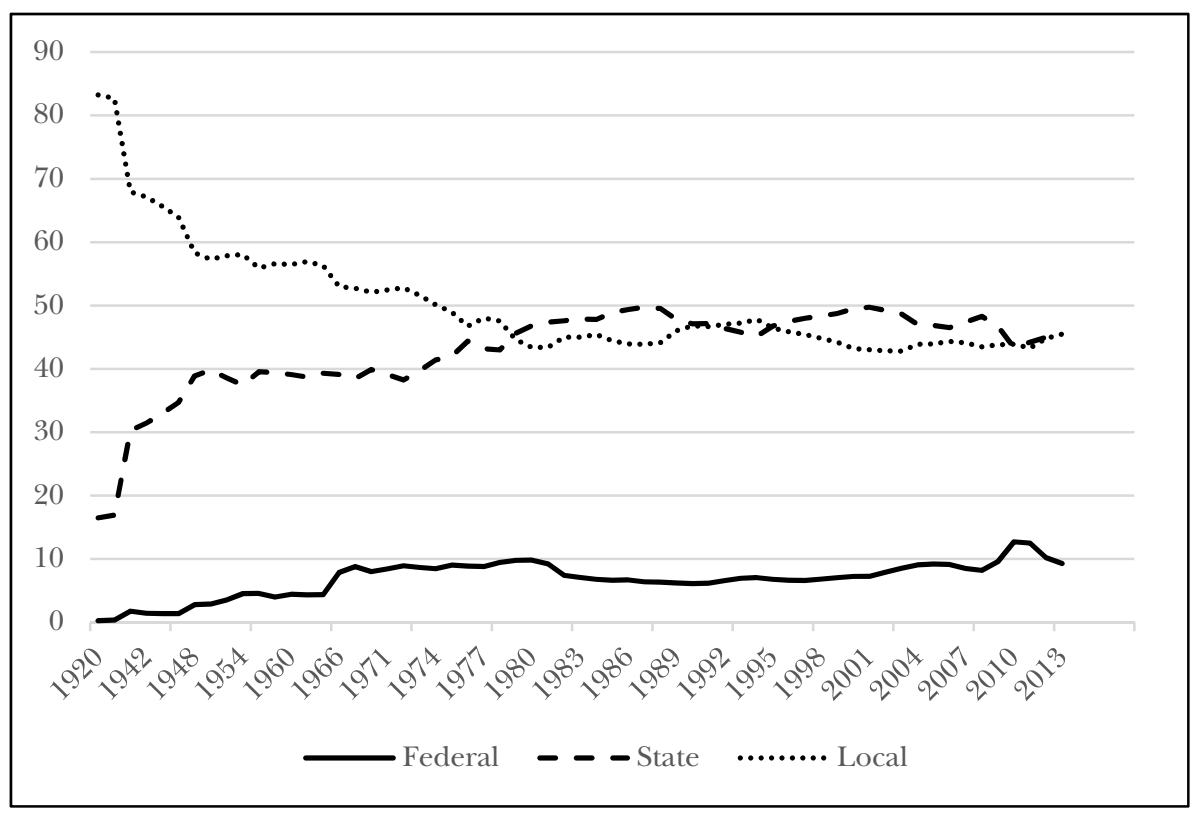

While the distribution of revenue among federal, state, and local sources conveys relative stability (post-1980), what Table 1 does not convey is the dynamic, real overall growth in per-pupil spending in America's public elementary and secondary schools over these same years. Table 2 illustrates that, despite a recent downturn beginning in the 2009-2010 school year, for almost the past century public school perpupil spending in the United States in real dollars displays a marked, steady increase over time. Interestingly, the combination of Tables 1 and 2 implies that one source of the per-pupil spending drop in 2010 can be attributed to an absolute and comparative reduction in state education spending triggered by the financial crisis.

As Table 2 illustrates, there has been a nearly unbroken trend of increased per-pupil spending since 1920, excepting school years following 2009. The timing of this important break and the financial crisis cannot, obviously, be ascribed to mere coincidence. Given the broad and deep financial devastation of the crisis, its deleterious implications for public and private budgets are similarly unsurprising.

178. Nat'l Ctr. for Educ. Statistics, Digest of Education Statistics: Table 235.10. Revenues for Public Elementary and Secondary Schools, by Source of Funds: Selected Years, 1919-20 Through 2012-13 (2015), http://nces.ed.gov/programs/digest/d15/tables/dt15_235.10.asp [http://perma.cc/PC3N-SU5U]. 
Table 2: Total ANNUAl Per-Pupil ExPEnditure (In Constant 20142015 DOLLARS), 1920-2013

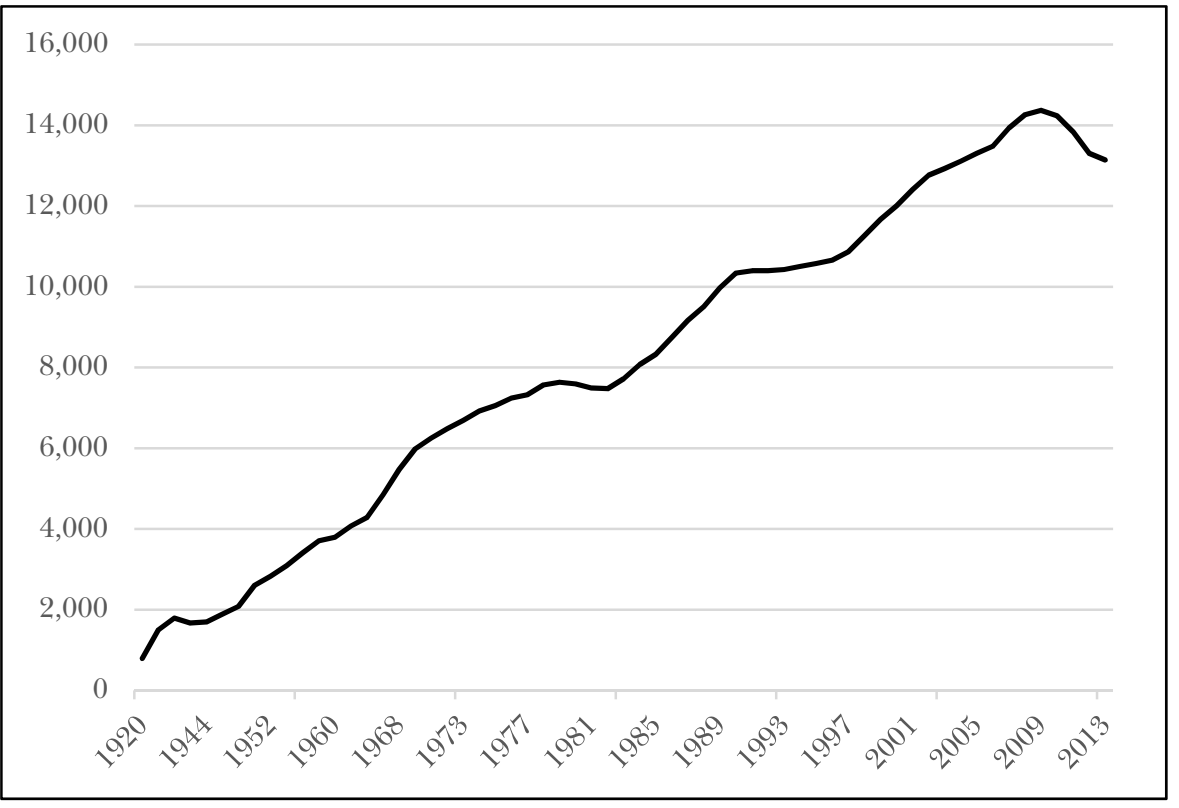

2. Consequences for School Choice. - Lurking beneath the obvious consequences of the 2007-2008 financial crisis are less obvious and more subtle effects. As the per-pupil spending trend data in Table 2 illustrates, the 2007-2008 financial crisis clearly impacted education spending. As the data in Table 2 are aggregated across all districts by year, what is not illustrated is important across-district variation. Variations aside, Professor Black describes the financial consequences of the "Great Recession" to public school districts in blunt, dramatic terms. ${ }^{180}$ Setting aside the primary fallouts-including often dramatic reductions in raw cash flow to many school districts—scholars have also noted additional secondary and tertiary consequences, albeit subtle ones, that may contribute to a further

179. Nat'l Ctr. for Educ. Statistics, U.S. Dep't Educ., Digest of Education Statistics: Table 236.55. Total and Current Expenditures per Pupil in Public Elementary and Secondary Schools: Selected Years, 1919-20 Through 2012-13 (2015), http://nces.ed.gov/ programs/digest/d15/tables/dt15_236.55.asp [http://perma.cc/US7D-9NZ6].

180. See Derek W. Black, Averting Educational Crisis: Funding Cuts, Teacher Shortages, and the Dwindling Commitment to Public Education, 94 Wash. U. L. Rev. 423, 424 (2016) (describing the impact as a "crisis" and noting that "[s]ome states experienced massive cuts for multiple years"). 
devolution of education decisionmaking authority from governments to families and students. ${ }^{181}$

Along with its impact on public education funding, the 2007-2008 financial crisis financially devastated many households. ${ }^{182}$ Given the financial crisis's magnitude, the collateral damage inevitably included some children, specifically moving some children from private schools back to public schools. Thus, students who previously attended private schools now found themselves in public schools owing to familial financial exigency. Some of these students and their families undoubtedly brought their preferences for greater school choice with them and began to push for greater public and publicly funded school choice. While parental demands for greater control over schooling options for their children predated the financial crisis, an influx of students from families predisposed toward greater school choice, as demonstrated by their preference for private school, into public schools will likely steepen the overall demand curve for greater parental autonomy.

\section{Demand for Public School: A Comparatively Smaller Slice of a Shrinking Pie}

An increasing demand for non-public school alternatives has over time eroded public schools' market share of students. At the same time, demographic data convey a relatively static supply of school-age children. While the raw number of school-aged-defined as five- to seventeen-yearold-resident Americans between 2000 and 2010 suggests minimal growth, specifically around 1\%, assessing school-aged, resident Americans as a percentage of the total resident population demonstrates a $1.5 \%$ decline from $18.9 \%$ to $17.4 \%$ in the same period. ${ }^{183}$ If one goes back to the 1969-1970 school year, the drop climbs to around $8 \%$, from $25.8 \%$ to $17.4 \% .{ }^{184}$ Thus, the interaction of a demonstrably increasing appetite for school choice and a static supply of school-age children more accurately captures the contours of the challenges now confronting public schools and their potential customers.

181. I appreciate Professor Black for raising this intriguing new, subtle wrinkle with me. He also briefly notes this possibility in Derek W. Black, The Constitutional Compromise to Guarantee Education, 70 Stan. L. Rev. (forthcoming 2018) (manuscript at 66-68) (on file with the Columbia Law Review).

182. See, e.g., Michael D. Hurd \& Susann Rohwedder, Effects of the Financial Crisis and Great Recession on American Households 5 (Nat'l Bureau of Econ. Research, Working Paper No. 16407, 2010), http://www.nber.org/papers/w16407.pdf [http://perma.cc/J7KN-459Y] (finding "widespread" effects of the recession on American households); see also Melissa B. Jacoby, Bankruptcy Reform and the Financial Crisis, 13 N.C. Banking Inst. 115, 115-16 (2009) (discussing bankruptcy reforms incident to the 2008 financial crisis).

183. See Nat'l Ctr. for Educ. Statistics, Digest of Education Statistics: Table 101.40. Estimated Total and School-Age Resident Populations, by State: Selected Years, 1970 Through 2014 (2015), http://nces.ed.gov/programs/digest/d15/tables/dt15_101.40.asp?current=yes [http://perma.cc/3DCS-GLKC].

184. Id. 
A comparatively decreasing appetite for traditional, "assigned" public schools raises important social, political, and economic issues for public schools and school officials. To the extent that any stigma previously existed for those families who, for whatever reason, opted out of their assigned public schools, ${ }^{185}$ that stigma attaching to families seeking schooling alternatives has dissipated, as non-assigned-publicschool and non-public-school attendance has increased, both in absolute and relative terms.

Politically and economically, the stakes are even higher for public schools. While the politics surrounding school choice policies are anything but clear, political support for public schools remains important, indeed critical. Insofar as public school budgets are a function of a public's willingness to tax itself, public schools' financial health depends on popular political support for public schools. ${ }^{186}$ Families who opt out of public schools altogether likely absorb private school tuition on top of their property tax contributions, which help fund local public schools. As a result, their appetite to "invest" in local public schools likely diminishes, at least at the margins.

To be sure, it remains important to note that property owners retain an economic incentive to support even those local public schools that their kids do not attend. After all, in many districts, including many affluent suburban districts, homeowners pay a premium for property located in a public school district benefitting from a favorable reputation. ${ }^{187}$ Given the direct economic relation between perceptions of public-school-district quality and property values, even property owners without school-age children or those with children who have opted out of public schools still have an important economic incentive to help ensure that positive perceptions of the assigned school district persist.

These constantly evolving political, social, and economic dynamics help fuel political turbulence surrounding school choice that increasingly straddles traditional political labels and exhibits complex political

185. See generally Diane Ravitch, Reign of Error: The Hoax of the Privatization Movement and the Danger to America's Public Schools (2013) (arguing for an end to the privatization movement, which drains students and funding from public schools); David Cutler, The Private-School Stigma, Atlantic (Jan. 21, 2015), http://www.theatlantic.com/ education/archive/2015/01/bridging-private-and-public-schools/384673/ [http://perma.cc/ AG7Q-332H] (discussing ways in which the reform community vilifies non-public-school students and teachers).

186. See Jonathan B. Baker \& Steven C. Salop, Antitrust, Competition Policy, and Inequality, 104 Geo. L.J. Online 1, 8 (2015), http://georgetownlawjournal.org/articles/ 164/antitrust-competition-policy-inequality/pdf [http://perma.cc/H7MN-W4HB] (observing that "it has long been suggested that private schools reduce political support for larger public school budgets").

187. See, e.g., William T. Bogart \& Brian A. Cromwell, How Much More Is a Good School District Worth?, 50 Nat'l Tax J. 215, 230-31 (1997) (finding "high-quality school districts provide services valued in excess of the higher taxes that they levy"). 
dynamics. ${ }^{188}$ To be sure, Republican administrations have been comparatively more hospitable to the idea of increased competition among schools, including public schools. ${ }^{189}$ One recent example is President Trump's initial address to a joint session of Congress in January 2017, in which Trump made clear his Administration's support for, among other education reforms, publicly funded voucher programs that expressly include homeschooling. ${ }^{190}$ The drive at the federal level for increased competition among schools is not confined to Republican administrations, however. As Diane Ravitch, a staunch and vocal school choice critic, notes, the "Obama administration [was] just as enthusiastic about privately managed charter schools as the Republicans." ${ }^{191}$ Consequently, contributing to the political complexities surrounding school choice is that traditional, reliable political "markers" increasingly do not provide much predictive force in the education context.

\section{WHAT A FOCUS ON TRADITIONAL EDUCATION FEDERALISM RISKS MISSING-AND WHY IT MATTERS}

An ongoing federalism "tug-of-war" between the federal and state governments, as well as among the federal branches, over education policy control shows no sign of abating anytime soon. Indeed, if anything, the juxtaposition of NCLB and ESSA, along with the controversy surrounding the confirmation of President Trump's Secretary of Education, Betsy DeVos, makes quite clear that fights over education federalism boundaries are, if anything, heating up. These boundary fights, particularly in light of recent political turbulence, will also continue to attract scholarly and public attention. And, to be sure, the distribution of education policy authority-both horizontally and vertically-deserves some attention, as who decides can often be as, if not more, important as what is decided.

188. See, e.g., Ryan \& Heise, supra note 9, at 2080-81 (discussing the underappreciated political resistance to voucher programs from many Republicans in affluent suburbs despite Republican leaders' support for vouchers).

189. For example, past Republican administrations have pressed for publicly funded voucher programs that include private religious schools. See, e.g., Lizette Alvarez, Senate Rejects Tuition Aid, a Key to Bush Education Plan, N.Y. Times (Jun. 13, 2001), http://www.nytimes.com/2001/06/13/us/senate-rejects-tuition-aid-a-key-to-bush-educationplan.html (on file with the Columbia Law Review). See generally John C. Jeffries, Jr. \& James E. Ryan, A Political History of the Establishment Clause, 100 Mich. L. Rev. 279, 350-51 (2001) (noting the Reagan and Bush Administrations' general support for greater school choice, including public funding for parents who want to send their children to religious schools).

190. See Yamiche Alcindor, Trump's Call for School Vouchers Is a Return to a Campaign Pledge, N.Y. Times (Mar. 1, 2017), http://www.nytimes.com/2017/03/01/ us/politics/trump-school-vouchers-campaign-pledge.html?_r=0 (on file with the Columbia Law Review).

191. Ravitch, Private, supra note 136, at 58. 
An undue focus on formal education federalism boundary disputes and the allocation and reallocation of policy control between federal and state governments, however, risks missing an equally and, potentially, more profound important structural shift in power. School choice, in all its various forms exercised by parents and students, continues to increase in both absolute and relative terms. One inevitable consequence of school choice policies is that they reduce governmental control over the education enterprise in a fundamental manner. An increase in school choice results in an unmistakable shift in power over critical educational decisions concerning elementary and secondary schooling away from government (at all levels) and toward parents and their schoolchildren. While reasonable people of good will can and do differ over the policy implications and wisdom of such a shift in authority, as a descriptive matter, evidence of this shift appears quite clear. Moreover, even school choice critics understand and acknowledge that parents have a legal authority to exercise their rights in ways that public school districts cannot. ${ }^{192}$ The resulting shift in control over school assignments from governments to parents possesses quite important implications for education federalism, albeit in an indirect manner. While control over education policy—particularly public education policy—can dramatically influence schools, as more parents gain control over where their kids go to schools, jurisdictional squabbles among governmental units over what happens within schools will decline in importance.

Given the explosive market developments, homeschooling, with its potential to disrupt traditional education markets and further contribute to the diminished relevance of current education federalism turbulence, warrants particular attention. While it is difficult to accurately assess how the dramatic growth of quality online curricula and resources will continue to inform homeschooling's popularity over time, a few points are already clear. First, at its core, education remains a labor-intensive activity, whether delivered in traditional schools or in the home. On this point, status quo largely endures, and homeschooling remains limited only to those who can absorb (or organize) and meet the intensive labor requirements. While technology, including online instruction, can reduce this burden, technology cannot—at least not yet—substantially eliminate the fixed labor requirements. Technological developments can reduce, however, other traditional market barriers, including, for example, access to instructional material. ${ }^{193}$ The potentially significant reduction of one traditional barrier to the homeschooling market will likely steepen homeschooling's growth trend going forward.

192. See, e.g., Julie F. Mead \& Maria M. Lewis, The Implications of the Use of Parental Choice as a Legal "Circuit Breaker," 53 Am. Educ. Res. J. 100, 100-01 (2016) (highlighting parental choice as a means of evading legal limitations on public actors and governmental authorities).

193. To reference just one obvious example: Access to the Internet now makes available a growing plethora of high-quality learning material. 
To argue, as this Essay does, that increased school choice will diminish the comparative importance of education federalism squabbles is not to argue that education federalism will become unimportant. Obviously, and for good reasons, federalism boundaries matter, as they should, and they will continue to matter in the education context and elsewhere. On the horizontal axis, important questions about whether education policy is or should be primarily an executive or legislative function will persist. President Trump's recent decision to formally withdraw a "Dear Colleague" letter concerning transgender school-bathroom access is one recent example of this ongoing structural separation of power tension and one that has already yielded palpable legal and policy consequences. ${ }^{194}$ To the extent that both branches will continue to participate, fights over policy control between Congress and the Executive Branch will not go away, particularly when political control over Congress and the presidency is divided between Republicans and Democrats.

Similarly, as the quick transition from NCLB to ESSA amply illustrates, analogous fights over education policy will endure between the federal and state governments (and, in a similar manner, between state governments and local school districts). The evolving composition of school budgets from federal, state, and local sources contributes to and, indeed, exacerbates vertical separation of power tensions. ${ }^{195}$

\section{CONCLUSION}

Acknowledging that education federalism concerns will likely-and appropriately-endure, however, does not diminish this Essay's central point: that a focus on education federalism and its related squabbles risks missing a critical shift in education control occasioned by increased demand and capacity for school choice, broadly defined. School choice shifts fundamental power from governments at all levels to parents and their schoolchildren. Such a move restructures the balance of power between governments and citizens with respect to school attendance and materially disrupts a status quo that structurally favors public school attendance.

Given the importance of education to an individual's ability to participate fully in the nation's economic, political, and social realms, that states compel some amount of education is unremarkable. ${ }^{196}$ Equally unremarkable, however, is that our constitutional values, expressed by the Court in Pierce v. Society of Sisters, allow individuals the ability to

194. See supra section I.B.1.

195. See supra Table 1 .

196. For a tabular summary of state compulsory education laws as of 2015, see Nat'l Ctr. for Educ. Statistics, State Readiness and Progress Through School: Table 5.1. Compulsory School Attendance Laws, Minimum and Maximum Age Limits for Required Free Education, by State: 2015, http://nces.ed.gov/programs/statereform/tab5_1.asp [http://perma.cc/4NWX-GVE7] (last visited Aug. 7, 2017). 
discharge their affirmative schooling obligations through public- and non-public-school attendance. ${ }^{197}$ The distribution of families able to fully exercise their Pierce rights, however, predictably skews in a direction that favors the wealthy over the poor. ${ }^{198}$ To the extent that school choice policies increase education autonomy for a greater number and percentage of families, a corresponding shift in power from governments to families will result.

197. 268 U.S. 510, 534-45 (1925) (holding that a statute may not constitutionally require that children receive their mandatory schooling from only public schooling).

198. Another variant of families exercising their "Pierce rights" is when those families with the economic ability to do so select to live in districts with high-performing public schools. Not surprisingly, such districts typically correlate with comparatively higher property values. See Bogart \& Cromwell, supra note 187, at 231. 